\title{
СТАТЬИ
}

DOI: http://doi.org/10.15688/nav.jvolsu.2017.2.1

UDC 903.08

LBC 63.4(3)

\section{THE ORIGIN OF THE TAMGAS OF THE XIONGNU}

\author{
Evgeniy S. Bogdanov
}

Institute of Archaeology and Ethnography, Siberian Branch of RAS, Novosibirsk, Russian Federation

\begin{abstract}
The article analyzes the whole corpus of sources on the tamgas of the Xiongnu. The author reveals the reasons for the emergence of tamga-like symbols in the culture of nomads, based on a circle. Analysis of the available material made it possible to suggest that the tamgas of the Xiongnu could appear on the basis of Chinese traditional symbols and hieroglyphs. The process of the birth of ancestral signs took place on the background of fundamental changes in the hieroglyphic writing in the Chinese empire, therefore each tamga was actually an ideograph expressing the basic idea, the concept. The end discs of the shingles of the Han epoch, especially from the territory of Mongolia and Inner Mongolia, represent the most important key to understanding the principles of tamgas emergence. The Xiongnu leaders' need to have their own signs, reflecting the solar symbolism and emphasizing the original connection of nomadic families with the Sky - was a historical necessity as opposed to Han China. In the future it was the movement to the West of the Xiongnu tribes - adopters of the Han traditions that influenced the emergence of such tamgas in the Sarmatian world. Such a powerful "transmission" in regions took place only when the power was seized by a "military group", which had its own powerful ideological foundation based on mythological postulates, which of course could change over time. For the ordinary Sarmatian population, the "transmission" of the main mythologemes passed through sacral objects, in particular through mirror-pendants with ideographs of hieroglyphic origin) - the copies of ornamental patterns from Han tiles and mirrors. The article clearly traces the change of the tamga formation principle in the process of penetrating the Sarmatian milieu. Each "additional element" could become an "independent unit", showing "the growth of the genealogical tree".
\end{abstract}

Key words: Sarmatian cultures, tamgas of the Xiongnu, Han epoch, ideograph, mirror-pendants.

Citation. Bogdanov E.S., 2017. The Origin of the Tamgas of the Xiongnu. The Lower Volga Archaeological Bulletin, vol. 16, no. 2, pp. 5-32. (in Russian).

УДК 903.08

ББК 63.4(3)

\section{ПРОИСХОЖДЕНИЕ ТАМГ ХУННУ}

\section{Евгений Сергеевич Богданов}

Институг археологии и этнографии СО РАН, г. Новосибирск, Российская Федерация

Аннотация. В статье проанализирован весь корпус источников по тамгам хунну. Выявлены причины возникновения в культуре кочевников тамгообразных знаков, в основе которых лежит круг. Анализ имеющегося материала позволил высказать предположение о том, что тамги хунну могли появиться на базе китайских традиционных символов и иероглифов. Процесс возникновения родовых знаков проходил на фоне коренных изменений в иероглифическом письме в Китайской империи, поэтому каждая тамга была по сути идеографом, выражающим основную идею, понятие. Важнейшим ключом к пониманию принципов возникновения тамг являются концевые диски черепицы эпохи Хань, особенно с территории Монголии и Внутренней 
Монголии. Возникшая потребность у вождей хунну иметь собственные знаки, отражающие солярную символику, подчеркивающую изначальную связь кочевых родов с Небом, была исторической необходимостью в противовес Ханьскому Китаю. В дальнейшем именно передвижение на Запад хуннских племен, перенявших ханьские традиции, повлияло на появление подобных тамг в сарматском мире. Такая мощная «трансляция» в том или ином регионе, происходила только тогда, когда власть захватывала «воинская группировка», имеющая свою мощную идеологическую основу, базирующуюся на мифологических постулатах, которые, конечно, с течением времени могли претерпевать изменения. Для рядового сарматского населения «трансляция» основных мифологем проходила через сакральные предметы, в частности, через зеркала-подвески с идеографами (иероглифическими по своему происхождению) - копиями орнаментальных схем с ханьских черепиц и зеркал. В статье удалось четко проследить, как по мере продвижения в сарматскую среду менялся принцип тамгообразования. Каждый «дополнительный элемент» мог стать «самостоятельной единицей», показывая «рост генеалогического древа».

Ключевые слова: сарматские культуры, тамги хунну, ханьская эпоха, идеограф, зеркала-подвески.

Цитирование. Богданов Е. С., 2017. Происхождение тамг хунну // Нижневолжский археологический вестник. Т. 16, № 2. С. 5-32.

Семь лет назад была опубликована замечательная статья А.В. Симоненко, в которой автор заострил внимание на факте наличия в сарматских культурах начиная с II в. до н.э. множества признаков, сближающих их с культурами хунну, Китая и скотоводов Южной Сибири [Симоненко, 2010, с. 392]. Однако публикация, к сожалению, не нашла должного отклика у исследователей, поэтому проблемы существования «гунно-сарматов» и особенностей становления искусства раннесарматской культуры так и остались в области высказанных ранее рассуждений о существовании торговых и культурных контактов, войн и брачных союзов [Лубо-Лесниченко, 1994, с. 230235; Гугуев, Трейстер, 1995; Безруков, 2000; Безуглов, Толочко, 2006]. Целью данной публикации является попытка оживить дискуссию и поговорить более предметно о фактах влияния китайской культуры на сарматский мир.

Начнем с частностей. Как справедливо отметил А.В. Симоненко, существование северного ответвления Шелкового пути не может объяснить появления в сарматском искусстве изображений животного в профиль, а его головы в фас, особенно когда звери показаны в характерных позах с вывернутым крупом. В то же время, наверно, не стоит считать эти художественные приемы «пазырыкскими» и элементами «хуннского прикладного искусства» [Симоненко, 2010, с. 395]. На мой взгляд, такая манера изображения изначально была характерна для традиционного Китая, как и собственно специфические образы (драконы, фениксы, единороги) [Богданов, 2006, с. 27-28].
Учитывая факт того, что большинство предметов из бронзы, серебра и золота, украшенных звериным орнаментом, было произведено по заказу хунну именно китайскими мастерами, вряд ли стоит говорить о влиянии «хуннского прикладного искусства» на сарматский звериный стиль, особенно, если иметь в виду спорность существования хуннского художественного феномена [Богданов, 2009].

Теперь переходим к главному. Если указанные выше особенности сарматского искусства можно объяснить эпохальной модой на социально статусные вещи и их престижностью, когда глубокий смысл сцен терзания и борьбы животных был понятен любому кочевнику, то факт широкого распространения во времени и пространстве реплик китайских зеркал со специфическим орнаментом в сарматской культурной среде нуждается в ином объяснении. «Торговые связи» и «мода» на престижные вещи не могут объяснить нижеследующих фактов.

Во-первых, ничтожно малое количество находок в сарматских погребениях собственно китайских зеркал и их фрагментов, при обилии их реплик.

Во-вторых, отмеченная В.К. Гугуевым, М.Ю. Трейстером и А.В. Симоненко особенность, заключающаяся в том, что китайские зеркала I в. до н.э. найдены в сарматских могилах более позднего времени, «запаздывая» на 70-100 лет [Гугуев, Трейстер, 1995, с. 150 ; Симоненко, 2010, с. 396]. Вряд ли предметы столетней давности были востребованы в торговых операциях на Шелковом пути. 
B-третьих, в Фергане, Прикаспии, Северном Кавказе, Подонье, Прикубанье, Северном Причерноморье и в Европейских степях копируются только определенные орнаментальные схемы китайских зеркал: с расположенными по кругу иероглифами и с солярной символикой в виде окружностей, спиралей, кругов с радиально расположенными лучами (рис. 1). Также активно и повсеместно производятся зеркала-подвески с «тамгообразными орнаментами», которые в точности повторяют оттиски с ханьской черепицы (рис. 2). Данные факты необходимо как-то объяснить, поскольку в самом Китае в ханьское время известны десятки типов и форм зеркал и десятки орнаментальных типов черепицы. Точка зрения В.С. Драчука о том, что «мотивы кругов» в «тамговых орнаментах» на зеркалах Северного Причерноморья, связанные с солярным культом, присутствуют на этой территории, начиная с эпохи бронзы [Драчук, 1975, c. 83], не имеет доказательной базы.

В-четвертых, анализ металла римских, эллинских и китайских зеркал свидетельствует, что римские бронзолитейщики использовали ханьские зеркальные сплавы, появившиеся в Китае не позднее VI в. до н.э. [Гугуев, Трейстер, 1995, с. 155]. В свою очередь, сарматские зеркала также близки к китайским бронзам, хотя никогда не повторяют в точности их состав [Равич, 1995, с. 162]. Причем речь идет не о торговле, а о собственном производстве. Т.Б. Барцева, исследовавшая металл сарматских зеркал-подвесок, сделала вывод, что они изготавливались в районах Северного Кавказа, а уже оттуда экспортировались в Северное Причерноморье и Прикубанье [Барцева, 1971, с. 136-138].

Таким образом, мы наблюдаем интересную ситуацию. Каким-то образом в сарматской среде оказываются точные рецепты изготовления зеркальных сплавов, вплоть до создания благородной черной патины, обладающей стеклообразным блеском [Равич, 1995 , с. 163]. Неожиданно массово и на огромной территории начинают активно использоваться орнаментальные схемы, характерные для традиционного ханьского Китая, в том числе с благопожелательной символикой (иероглифы). Объяснить все эти факты, исходя только из наличия торговых связей (или контрабанды) и «моды» на престижные вещи, не представляется возможным. Должны были существовать носители традиций, которые бы передавали имеющиеся знания. Изготавливая зеркала с определенным орнаментом, мастера (особенно при появлении первых образцов) и «потребители» должны были понимать смысл изображений, особенно если учитывать принятое за аксиому большинством современных исследователей положение о том, что в древних сообществах «зеркало в орнаментальной схеме символизировало систему мироздания». В.К. Гугуев и М.Ю. Трейстер предположили, что «китайские иероглифы в стилизованном виде могли ассоциироваться у населения Северного Причерноморья с тамгообразными знаками - племенными символами, мифологизированными в среде кочевого ираноязычного населения». А появление и распространение копий китайских зеркал связано с приходом волн кочевников из Средней Азии [Гугуев, Трейстер, 1995, с. 151]. А.В. Симоненко вслед за А.С. Скрипкиным считает, что китайские вещи попадали в сарматскую среду в результате миграции аланов на запад [Скрипкин, 1994, с. 33; Симоненко, 2010, с. 399]. «Аланская культура сформировалась в тесном взаимодействии с культурой хунну и под сильным влиянием китайской культуры. Скорее всего, потомки пазырыкцев (аланы) вместе с северными хунну после раскола империи двинулись на запад до Волги, Дона и Дуная» [Симоненко, 2010, с. 399]. С.Г. Боталов и С.Ю. Гуцалов вообще снимают множество вопросов, доказывая существование единой общности «гунно-сарматов» [Боталов, Гуцалов, 2000]. Все эти теории косвенно указывают на очень важный факт - в сарматскую среду были привнесены китайские орнаментальные и мифологические традиции, и это могло быть сделано только при участии какого-то кочевого сообщества, обитавшего долгое время рядом с Китаем. Еще сорок лет назад Б.И. Вайнберг и Э.А. Новгородова высказали предположение, принятое впоследствии большинством исследователей, что «тамги «юечжей дома Чжаову» (из Северо-Западного Китая), встреченные в Юго-Западной Монголии, Средней Азии, Центральном Казахстане и Северном Причерноморье, показывают путь продвижения группы кочевых племен от Мон- 
гольского Алтая и Джунгарии через Казахстан и Среднюю Азию в Восточную Европу» [Вайнберг, Новгородова, 1976, с. 71-72]. Эти тамги имеют довольно специфическую форму в виде круга (иногда перечеркнутого) и ответвлений - «усов» (реже «трезубца»). А поскольку их в середине XX в. зафиксировали в сочетании с рисунками хуннского времени, то и в археологической литературе прочно утвердилось мнение о том, что хунну взяли за основу юэчжийские тамги [Новгородова, 1984, с. 117118]. Очень странным представляется обстоятельство, что при огромных территориальных размерах хуннской державы скоплений тамг этого специфического типа среди петроглифов по существу известно всего четыpe: в местности Цагаан-Гол Монгольского Алтая (рис. 3,1-29) [Вайнберг, Новгородова, 1976, рис. 5; Пэрлээ, 1976, табл. V], в Хэнтийском аймаке Восточной Монголии, памятники Рашаан Хад, Дундэндэг-газар (рис. 3,3036) [Пэрлээ, 1976, № 86, 221, 28, 16, 40, 19, 79] и на скальных массивах Восточного Китая (рис. 3,37-46), памятник Сяньцзитань у д. Тайнэй, провинции Фуцзянь [Shanlin Gai, Yudong Lou, 1993, pic. 185, 186]. Таким образом, все местонахождения разделены между собой тысячами километров, а на территории современной китайской провинции Ганьсу (родине «юэчжей дома Чжаову») «энциклопедии» тамг вообще неизвестны.

Если говорить о предметах, то самая представительная коллекция такого типа тамг зафиксирована на донышках лаковой посуды из ноин-улинских курганов (рис. 4, 5,1-11) [Полосьмак, Богданов, 2016, с. 65-75]. Тамга такого же типа есть на дне берестяного «туеска» из кургана № 7 хуннского могильника Царам в Бурятии (рис. 5,14) [Миняев, Сахаровская, 2007, рис. 3,1]. Возможно, это была имитация чашки бэй, о чем свидетельствует специфическая форма донышка этого изделия. При анализе коллекции стоит обратить внимание на три нюанса.

Во-первых, тамгообразные знаки наносили только на дно чашек с внешней стороны. Исключение составляет предмет из шестого кургана, когда тамга в виде птицы нанесена на металлическую поверхность оковки ручки чашки (рис. 5,12a), поскольку на дне чашки красной краской уже были прописаны иероглифы
«Шанлинь», обозначающие название императорского парка и дворца [Чистякова, 2011, с. 85]. Если говорить о чашках бэй из ханьских погребений, раскопанных на территории Китая, то тамгообразные знаки встречаются на них чрезвычайно редко (рис. 5,13). Чаще фиксируются едва заметные метки (косые крестики, отдельные иероглифы), сделанные тонкой иглой при изготовлении посуды самими мастерами [Полосьмак, Чистякова, 2013, с. 89] ${ }^{1}$.

Во-вторых, в половине известных случаев на ноин-улинских чашках вырезано несколько тамг (рис. 5,1-2,5,8). И если это метки собственности, то значит, предмет принадлежал нескольким хозяевам. В-третьих, часть знаков процарапано тонкой иглой аккуратно и точно, а часть - прорезано нарочито грубо, по-варварски. Учитывая, что даже длинные иероглифические надписи, указывающие время изготовления, имена мастеров и чиновников, в некоторых случаях были сделаны по китайскому образцу, но не ханьцами в императорских мастерских [Чистякова, 2011, с. 85], то можно предположить, что все тамгообразные знаки на ноин-улинских чашках были нанесены уже во владениях хунну, в том числе и тамги в виде птичек (рис. 5,1-3,12a), являющиеся по существу копиями изображений китайских фениксов.

Тамгообразные знаки на астрагалах из могил и поселений хунну (рис. 6) являются, скорее всего, не метками собственности конкретных людей, а обозначением кочевого рода (клана) при проведении гадательных ритуалов или игры. Поэтому не случайно остальные знаки, процарапанные на альчиках, обозначают значимые события-понятия: «солнце», «лес», «колесница» и т. д. Причем подобный набор этих знаков в совокупности с тамгами начиная с I в. до н.э. встречается на астрагалах как на Востоке, так и на Западе [Шрамко, 1962, рис. 112; Древнемонгольские города..., 1965 , с. 295 ; Воронятов, 2013, с. 52-53, рис. 5]. Что касается производственных клейм на донышках хуннских сосудов в поле отпечатка шипа гончарного круга (рис. 7), большую часть из которых С.В. Воронятов называет тамгами [Воронятов, 2013, с. 48-49, рис. 1,1$2,4]$, то здесь не все так однозначно. Клейма китайских мастеров в большей части все-таки были иероглифами. Однако сложность данной темы подразумевает отдельную публикацию. 
Таким образом, имеющийся корпус археологических источников по хунну свидетельствует о довольно внезапном появлении на рубеже эр традиции наносить тамги на определенные категории вещей. Но почему у знаков такая специфическая форма и действительно ли знатные роды хунну взяли за основу юэчжийские тамги? Попробуем в этом разобраться.

В основе рассматриваемого типа тамг лежит круг, который мог быть разделен пополам, на три части или же иметь в центре точку. Б.И. Вайнберг и Э.А. Новогородова такой тип почему-то назвали «трехчленным» [Вайнберг, Новгородова, 1976, с. 69], хотя ответвлений - «усов», отходящих от основного круга, могло быть от одного до четырех (рис. 36). Ответвления всегда отходят от круга только под прямым углом. Это: S-овидный элемент $\mathcal{C}$, элемент в виде бараньих рогов Ю , в виде трезубца Пі, пламевидный §, U-образный U, иероглифический \pm , растительный $(\mathrm{H}$. Названия эти условны и даны только для удобства работы с материалом. Различные вариации элементов связаны, скорее всего, либо с фактурой камня (при выбивке появлялся схематизм), либо с усложнением знака (орнаментальность). Анализ этих элементов по отдельности и в совокупности с центральным элементом - кругом - позволяет высказать предположение о том, что тамги хунну могли возникнуть на базе китайских традиционных символов и иероглифов. Раскопки могил рядовых хунну и комплексов знати наглядно показали, что кочевники активно использовали в быту и погребальной практике предметы производства китайских мастеров (колесницы, шелк, оружие, одежду, украшения, посуду и др.). Эти предметы были мерилом не только социального статуса, но и в определенных случаях необходимостью для того времени. Ханьский Китай усмирял агрессивного соседа не только с помощью военных действий, но и после 200 г. до н.э. активно использовал политику «хэиинь» («мира, основанного на родстве») [Материалы..., 1968, с. 42, 44, 49, 73]. Это и периодическая отправка в ставку шанъюя китайских товаров и продуктов, и мощная «китаизация» кочевой среды. Как прозорливо говорил один из китайских перебежчиков: «Ныне вы, шаньюй, изменяя обычаям, проявляете любовь к ханьским изделиям, но если только две десятых ханьских изделий попадут к сюнну, то все сюнну признают над собой власть Хань» [Материалы..., 1968, с. 45]. И действительно, можно отметить, что китайские символы и образы с течением времени становятся узнаваемы и понятны в степи. Под заказ для хунну в большом количестве делаются различные предметы, с творческой переработкой основных сюжетов скифо-сибирского звериного стиля [Богданов, 2006, с. 26-28; 2009]. Именно поэтому практически все элементы тамг хунну мы можем увидеть на различных предметах китайского производства: на украшениях из нефрита, бронзовых изделиях, шелке, посуде, керамической черепице (рис. 8-10, 12). В основном это вариации облачного орнамента «юнь-вэнь», который имел свои специфические черты именно на территории Монголии и Внутренней Монголии (территории хуннской державы и в приграничных землях). Но есть и прямые аналогии. Например, очертания конского налобника из ханьского погребения (рис. 9,6) по существу повторяют контуры тамгообразного знака. Конечно, традиция, форма и система тамг не возникла в результате простого копирования элементов китайского орнамента. Здесь были заложены мощные идеи, касающиеся устройства Мира, мифологические аспекты. Ключом для их понимания могут служить нефритовые изделия с центральным отверстием (рис. 8,1,3,5), а также оттиски на ханьской черепице с иероглифами и различного типа пиктограммами (рис. 11). Например, если принять отверстие в нефритовой пластине за круг и визуально соединить его с элементом орнамента (рис. $8,1)$, то мы увидим очертания тамги из петроглифов Цагаан-Гола и Фуцзяня (рис. 3,5,40). Такая же тамга есть на донышке лаковой чашки из ноин-улинского кургана (рис. 5,7). Зафиксирована она на горе Кресхая (Хакасия) [Кызласов, 1994, с. 20], на каменных плитах с территории Боспорского царства (Северное Причерноморье) [Драчук, 1975, табл. XIII, рис. $3,49-53$, табл. XIV, рис. 13,3a,36] и Восточной Европы [Драчук, 1975, табл. XX, рис. 134]. В чуть видоизмененной форме мы видим этот знак в виде золотых бляшек на остатках ткани с золотым узорчатым шитьем из сарматского княжеского погребения [Медведев, 2008, с. 119, табл. 9а]. И таких примеров можно привести 
множество. Учитывая «популярность» этого знака, попытаемся на его примере понять механизм возникновения тамг у хунну.

Как уже было сказано выше, в основе хуннских тамг лежит круг, который почти во всех древних культурах ассоциируется с целостностью, всеединством (мира, космоса), замкнутостью и безопасностью (своего пространства) [Топоров, Мейлах, 1988, с. 18]. Для древнего Китая основными геометрическими фигурами являются круг и квадрат, символизирующие небо и землю. В надписях на «гадательных костях» и в чжоуской бронзовой эпиграфике (надписях на сосудах) слово «солнце» передавалось через графическую комбинацию, состоящую из круга с точкой посередине. Однако, начиная, по меньшей мере, с чжоуской эпохи, круг стал однозначно соотноситься именно с небом, что находит, в частности, отражение и в принятых истолкованиях нефритовых дисков-би. «В дальнейшем все производные от круга и квадрата геометрические фигуры стали наделяться такой же символикой, а любые варианты их сочетаний передают вертикально ориентированную космологическую модель и олицетворяют единство неба и земли как Мужского и Женского космических начал» [Кравцова, 2004, с. 358]. В этой связи невозможно не вспомнить два исторических свидетельства из китайских хроник. Первое о том, что циньские и ханьские правители именовали себя «Сын Неба» и считались обладателями всего пространства (земли и времени). Второе, что шаньюй каждое утро совершал поклонение солнцу, а каждый вечер - луне, принося в определенные дни жертвоприношения «небу, земле, духам людей и небесным духам» [Материалы..., 1968, с. 50]. То есть символ круга, круга с точкой, круга, разделенного пополам (день и ночь), мог быть понятен и ханьцам, и кочевникам, и однозначно соотносился с небесным светилом. С этой точки зрения использование круга в основе тамги - знака главного клана, рода вполне оправдано и имело в глазах соплеменников как мифологическую, так и социальную основу. Появление элемента «бараньих рогов» в верхней части тамги также вполне объяснимо. Китайский исследователь Чэнь Юнчжи, опираясь на археологические и письменные источники, считает, что «облачные узоры» в сочетании с орнаментом в виде бараньих рогов (янцзяо) на черепицах с территории Внутренней Монголии периодов Цинь и Хань отражают идею объединения государства (империи) и «единства Неба и человека». Особенную популярность янцзяо на черепицах он объясняет тем, что в период династии Хань большое число жителей Центральной равнины переселилось на северные территории, они стали разрабатывать земли, заниматься скотоводством [Чэнь Юнчжи, 2003, с. 26]. Здесь стоит обратить внимание не только на саму форму этих черепиц (солярную по сути), но и на строгий геометрический принцип построения орнамента. Как и на хуннских тамгах, «бараньи рога» соединяются с кругом (центром) по четырем сторонам под прямым углом (рис. $10,1-4,11,1,10)$, поскольку черепица делится на 4 части в форме иероглифа «十» (десять) [Го Бин, 2010, с. 156]. В центре черепичного диска в круге либо облачный орнамент, либо «шишка» (точка), либо животное и очень редко - геометрическая фигура (рис. 12). Тут же мы видим, что орнаментальное поле предмета заполнено S-овидными знаками, которые также чрезвычайно популярны как в земледельческих (Хорезм), так и в кочевых (скифы, сарматы, хунну, гунны и др.) культурах. Но только в Китае этот знак встречается повсеместно с эпохи бронзы. Эту же орнаментальную схему (с использованием круга, знака «бараньих рогов» и S-овидного знака) мы видим на бронзовых зеркалах из Китая (рис. $1,4,6)$ [Ван Ганхуай, 2015, с. 142, 158] и на зеркалах-подвесках из сарматских погребений (рис. 2,13-31). В этом смысле концевые диски черепицы, особенно с территории Монголии и Внутренней Монголии эпохи Хань, поистине бесценный материал для различного рода реконструкций не только по социальной истории Китая и особенностей взаимоотношений с варварами, но и важнейший ключ к пониманию принципов возникновения хуннских тамг, поскольку на черепицах есть оттиски не только орнамента, тамгообразные знаки (рис. 6,6, $11,9)$, но и китайские иероглифы. Большая часть надписей этого времени поддается прочтению современными исследователями. Иногда они содержат исторические свидетельства: «[Мы] с Шаньюем родственники», «Шаньюй спустился с Неба», «Победа над 
сюнну и признание сюнну вассальным государством» [Чэнь Юнчжи, 2003, с. 27, рис. 31,42,43]. Встречаются черепицы с именами конкретных удельных князей «хоу», например, «Гао Ань» (рис. 11,10) [Чэнь Юнчжи, 2003 с. 222] ${ }^{2}$. Но чаще всего на черепицы наносились различного типа благопожелания: «Долгих лет, вечного веселья, процветания», «Долгих лет», «Вечного веселья», «Богатства и долгих лет» (рис. 11,2-5,11,12) [Го Бин, 2010, с. 62, 65, 191, 196]. Точно такие же благопожелательные надписи наносились и на зеркала. Например, на фрагментах зеркала Западной Хань, найденного у с. Бейское, есть иероглифическая надпись, которая переведена Б. Карлгреном: «...пусть [зеркало] отгоняет злые влияния, пусть [Вы] будете таким же безграничным, как небо...» [Лубо-Лесниченко, 1975, рис. 5]. Тут очень важно отметить, что современными исследователями, по сути, дешифруется только смысл надписи, а что означают некоторые отдельные иероглифы или знаки, например, на ханьской черепице - в настоящий момент сказать сложно. Это связано с тем, что ни один современный иероглиф не сохранился в той форме, в которой он имел изначальную пиктографическую выразительность. То есть определение главного ключа (тематического классификатора, указывающего, к какой сфере относится значение иероглифа) не всегда очевидно. Известно, что в 213 г. до н.э. произошла унификация китайского письма по шести категориям знаков. «Первые две категории - «пиктограммы» сянсин (прообраз тамги) и знаки указательной категории чжиши. А пятая и шестая категории - «видоизмененные» чжуаньчжу и «заимствованные» изяизе знаки. Пятая категория, смысл которой был не ясен уже в I в. н.э., по-видимому, была представлена заимствованиями, отличающимися от исходных знаков несистемным искажением графики». В итоге 82 \% девятитысячного словника первого иероглифического словаря «Шо вэнь цзе цзы» («Объяснение простых и расчленение сложных знаков, 100 г. н.э.») составляют иероглифы унифицированного китайского письма, и только $13 \%$ - идеограммы [Духовная культура Китая..., 2008, c. 673]. То есть получается, что параллельно с возникновением тамг у кочевников, в ханьской империи проходила унификация письма, изменяющая коренным образом и написание, и чтение иероглифов. Учитывая сложность и растянутость по времени этого процесса, а также невысокий процент грамотности китайского населения, особенно в приграничных землях, можно предположить, что для передачи важной информации (в частности на черепице) пользовались самыми простыми формами выражения. Это должны быть знаки, символы, сохранившиеся с древности. Таким был знак «бараньих рогов», который существовал и как иероглиф (рис. 12,4) [Объяснение..., 2010 , с. 417], и как элемент традиционного китайского орнамента (рис. 10,1-4), и как элемент кочевнической тамги (рис. $3,5,5,7)$. То есть по существу во всех трех случаях мы имеем дело с идеографом, выражающим основную идею, понятие. Поэтому совершенно не случайным представляется наличие среди хуннских тамг Цагаан-Гола петроглифов «с изображениями людей с воздетыми к небу руками, в головных уборах в виде бараньих рогов» [Вайнберг, Новгородова, 1976, с. 69]. Но, даже выявляя в идеографе (тамге) ণृ два смысловых ключа - «солнце» и «рога», «прочитать» его однозначно было бы не правильно. Поясним это на нескольких примерах. «Бык» в ханьское время мог обозначаться иероглифом в виде «трезубца» с перпендикулярной чертой в нижней части (рис. 12,1) [Объяснение..., 2010, с. 17, 259], а с двумя чертами - это уже понятие - «рождаться» (рис. 12,10) [Духовная культура..., 2008, рис. на с. 658]. Знак 半 означал «дерево», «злак», (рис. 12: 34) [Объяснение..., 2010, с. 133, 364], а с кругом по центру 单 - «восток» (сочетание «солнца» и «дерева»), отражение события - восхода солнца [Объяснение..., 2010, с. 81, 83]. Как предположил С.В. Алкин в личной беседе, возможно, в этом знаке отражено передвижение солнца с востока на запад, поэтому оно показано в середине ${ }^{3}$. Тот же элемент в виде круга, разделенного на четыре части, есть в иероглифе варвар» (рис. 12,5). «В Шо вэнь разъяснено, что след зверя на поле - это и есть фань» [Объяснение..., 2010, с. 92]. Знак в благопожелательной надписи на черепице (рис. 11,6) «Сладкая ключевая вода протекает через двор» мог означать «нити жемчуга или драгоценных камней, свисающие с головного убо- 
ра императора или высокопоставленного чиновника» [Го Бин, 2010, с. 197]. Иероглиф \$ํํ имел значение «внук» [Объяснение..., 2010, c. 343], что выводит нас на очень интересные семантические параллели при сравнении с идентичными тамгообразными знаками Монголии и Северного Причерноморья [Вайнберг, Новгородова, 1976, рис. 7, табл. II]. Как видно из приведенных примеров, «идеографы» ханьского времени (как и тамги) могли читаться по-разному в зависимости от количества и формы составных частей. Структура их написания и отдельные элементы указывают на то, что процесс создания тамг хунну проходил под влиянием китайцев. Об этом свидетельствует центральное положение в тамге круга (солнца), отражающее понятие «жизни», «рождения», «цикличности и бесконечности». Все дополнительные элементы (S-овидный элемент, элемент в виде «бараньих рогов», в виде «трезубца», «пламевидный», «U-образный», «линейный», «растительный») могли появиться как часть пиктографического письма, и отражали какие-то особенности определенного кочевого рода или клана. В этой связи чрезвычайно любопытно появление элемента $\mathcal{V}$ в хуннских тамгах, учитывая наличие его не только на ханьских черепицах (рис. 10,10), но и его безусловное сходство с так называемыми «П-образными знаками» на оленных камнях Монголии [Вайнберг, Новгородова, 1976, рис. 6] и скалах Кочкорской долины (Киргизия) [Самашев и др., 2010, рис. 92, 94]. В данном случае, мне представляется, что знак, безусловно, обозначал важную деталь - распределитель вожжей (рис. 13), и в составе тамги (рис. 5,5,6) мог символизировать как саму колесницу, так и колесничего. Возможно, в сочетании с кругом (центральным элементом) такая тамга становилась знаком «небесной колесницы».

Таким образом, анализ исторической ситуации в регионе, где впервые появились кочевые тамги с центральным элементом в виде круга, а также все имеющиеся изобразительные источники, позволяет усомниться в юэчжийском происхождении этих идеографов. Так же вряд ли можно согласиться с Х. Йэнихеном в том, что «символические изображения неба и земли, вселенной в виде треугольника, круга и ромба» как составные элементы сложных знаков попали в сарматский мир из Ирана [Jänichen, 1956, p. 40-41]. Скорее всего, возникшая потребность у вождей хунну иметь собственные знаки, отражающие солярную символику, подчеркивающую изначальную связь кочевых родов с Небом, и имеющие свои специфические черты, была исторической необходимостью в противовес Ханьскому Китаю. Эти процессы проходили на фоне коренных изменений в иероглифическом письме в Китайской империи, поэтому логично предполагать скорее участие ханьцев в процессе тамгообразования, нежели юэчжей. Хотя это совсем не означает, что у юэчжей не могло быть тамг. В дальнейшем именно передвижение на Запад хуннских племен, перенявших ханьские традиции, повлияло на появление подобных тамг в сарматском мире. Только прямой «трансляцией традиций» можно объяснить появление тамг на монетах, гадательных костях, сосудах, зеркалах и на скалах (каменных плитах) на территории западной ойкумены, поскольку нанесение знаков (символов) на указанных категориях предметов (причем, в большей мере ценных предметов!) и природных объектах было характерно именно для Китая. Такая мощная «трансляция» в том или ином регионе происходила только тогда, когда власть захватывала «воинская группировка» (можно назвать ее так), имеющая свою мощную идеологическую основу, базирующуюся на мифологических постулатах, которые, конечно, с течением времени могли претерпевать изменения. Например, мы имеем вполне доказанный факт прихода кочевников в Хорезм, захват власти и, как следствие, появление специфических тамг на монетах [Вайнберг, Новгородова, 1976, c. 70-71]. Распространение знаков с солярной составляющей (кругом в центре) и строительство храмов, посвященных солнцу в Средней Азии (Мерв, Фергана), возможно, представляют явления, тесно связанные между собой. Сходные события произошли и на Боспоре [Яценко, 2001, с. 45-47]. Причем и в Средней Азии и на Боспоре существовала вполне благоприятная почва в связи с существующими древнеиранскими представлениями о «фарне», божественном (солнечном) сиянии [Литвинский, 1968, с. 63-82]. В графическом виде фарн часто изображался в виде бараньих 
рогов и поэтому, например, выбор тамги Ф для правящей элиты был совсем не случаен. Что касается рядового сарматского населения, то «трансляция» основных мифологем проходила через сакральные предметы, в частности, через зеркала-подвески с идеографами (иероглифическими по своему происхождению) - копиями орнаментальных схем с ханьских черепиц и зеркал (рис. 1-2).

Не вдаваясь в дискуссию по методическим вопросам изучения сарматских тамг [Cоломоник, 1959; Драчук, 1975; Ольховский, 2001; Яценко, 2001; Воронятов, 2009; 2013; Самашев и др., 2010; Подушкин, 2013 и др.], следует отметить, что подходить к сравнению и утверждениям о сходстве хуннских и сарматских (среднеазиатских) тамг следует чрезвычайно осторожно, особенно в вопросах генезиса форм сложных знаков (по времени или по «родственным связям»). Основные пункты можно свести к трем положениям.

1. Следует отказаться от сравнительного анализа простых знаков типа «круга», «креста», «скобки», «елочки», «S-овидной формы», поскольку они являются проявлением универсальности человеческого мышления независимо от конкретной эпохи и конкретного региона. Не случайно практически все эти знаки присутствуют в составе рунического письма и различных более поздних алфавитов.

2. В контексте выделенного типа хуннских тамг можно говорить на начальном этапе о существовании центрального элемента круга (основной род) и дополнительных элементах (родственные кочевые кланы). По мере продвижения в сарматскую среду менялся принцип тамгообразования. Каждый «дополнительный элемент» мог стать «самостоятельной единицей», показывая «рост генеалогического древа». Вариантов могло быть

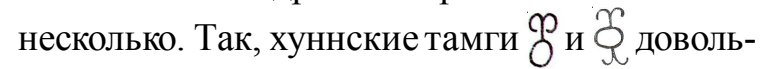
но часто встречающиеся в сарма̄тском мире [Кызласов, 1994, с. 20; Драчук, 1975, табл. ХІІІ, рис. 3,49-53; табл. XIV, рис. 13,3a,3б; Вайнберг, Новгородова, 1976, рис. 7], ввиду мощного символического значения проявились даже в схемах «царских» родов (например, боспорского царя Инисмея) [Симоненко, Лобай, 1991, рис. 33]. Но в отличие от хуннских образцов, «круг» уменьшился в размерах. В более позднее время скопление тамг с та- кой схемой и пропорциями мы видим и на Востоке: например, на Бомбогорской стеле в Монголии, связываемой уже с тюрками [Caмашев и др., 2010, рис. 42]. На тамгах «царского дома» Фарзоя круг вообще отсутствует при сохранении «дополнительных» элементов [Воронятов, Мачинский, 2010, рис. 1]. Если принять точку зрения В.С. Драчука о том, что «нижняя часть - символ правящей боспорской династии» не изменялась со временем, а «изменениям была подвержена только верхняя часть царских знаков сложной формы» [Драчук, 1975, с. 62], то получается, что «смысловым центром» данного типа тамг становится элемент «бараньих рогов». Вряд ли это просто совпадения, особенно если учитывать встречающуюся полную идентичность знаков $\mathcal{~ с ~ х а н ь с к о и ̆ ~ ч е р е п и ц ы ~ ( р и с . ~} 10,11 ; 11,8$ ) и сарматских (среднеазиатских) тамг. Например, мы видим такой знак на чаше из Косики [Симоненко, Лобай, 1991, рис. 33,11], на зеркалах из Поволжья и на монетах из Хорезма [Драчук, 1975, табл. XIII,564; XVI,20; XVIII, рис. $1,11,12]$. Интересно, что в тамгах сарматских вождей присутствуют также $\mathcal{V}$ и $\int$ элементы хуннских тамг [Драчук, 1975, табл. V, X, XII, XIII; Симоненко, Лобай, 1991, рис. 32,46,10; Воронятов, 2009, рис. 3,2]. Символом отдельных правящих «династий» в Сарматии и Хорезме стал китайский по своему происхождению идеограф Пл «дерево». И если учитывать присутствие \ элемента «колесница» в хорезмийских тамгах, то может быть не так уж был не прав С.П. Толстов, усматривая связь сложных сарматских знаков с сиявушидскими тамгами, в которых «изображения дерева слились с протомами коней, повернутых головами в стороны» $\hat{\imath}$ [т [Тлстов, 1948, с. 185]. Тот факт, что по мере продвижения на Запад из схем тамг исчезает круг (основной элемент), не должен вызывать удивления. Еще на ранних этапах у хунну есть тамги без солярного знака, который заменяют одна или две черты (рис. $3,14,15,6,6,11,9)$. Это опять же указывает на тесную связь с китайской традиционной культурой, так как графический элемент ط присутствует еще в пиктограммах знака $\partial u$ на китайских гадательных костях (II тыс. до н.э.) и трактуется в тесной связи с «женским предком», «культом Матери-прародительницы» [Серкина, 1973 , c. 28-33]. 
E.S. Bogdanov. The Origin of the Tamgas of the Xiongnu

3. Тамги (идеографы) с центральным элементом в виде круга не позволяют говорить о процессах «упрощения сложных форм» или «усложнении простых форм». В изменениях этого типа тамг прослеживается скорее мифологический и идеологический смысл, нежели существование строгой иерархии, идущей по линии развития от простого к сложному или наоборот.

Предложенный в данной статье вариант происхождения тамг хунну и причин по- явления китайских орнаментальных схем (мифологем) в сарматских культурах является дискуссионным. Появление нового изобразительного материала из хуннских археологических памятников, а также с территории Средней Азии и Кавказа может существенно помочь в решении проблем возникновения ранних типов тамг и более четко проявить векторы продвижения конкретных кочевых групп из глубин Центральной Азии на Запад. 


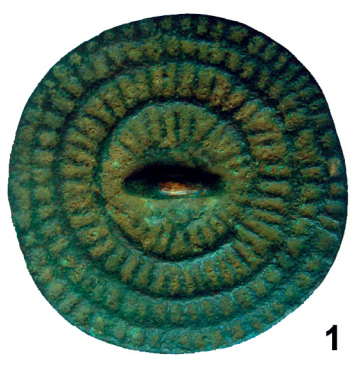

\section{ИЛЛЮСТРАЦИИ}
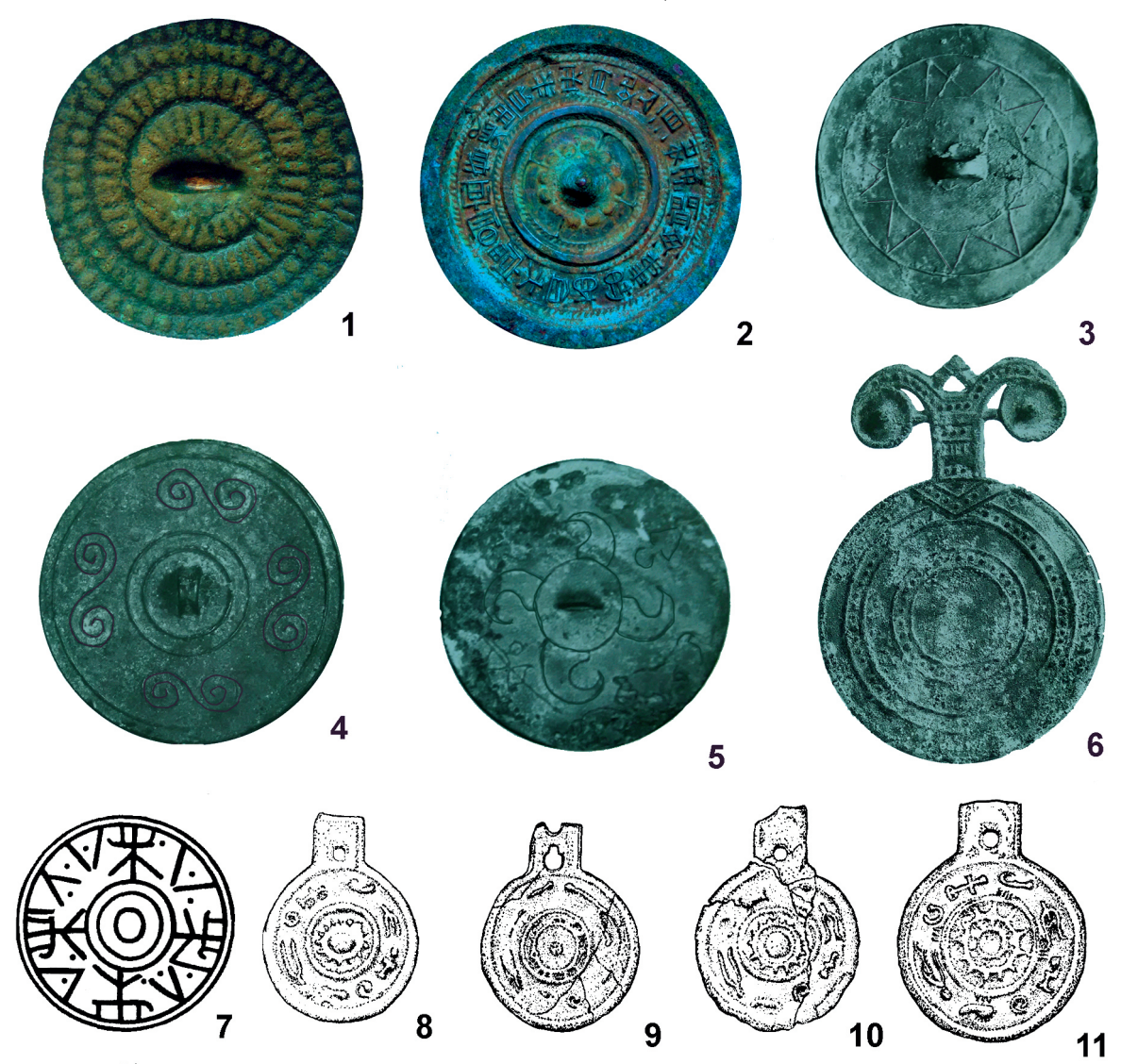

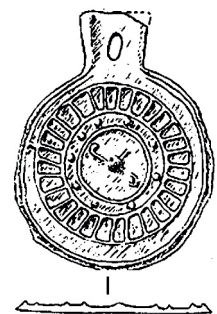

12

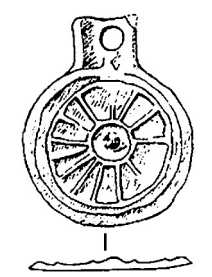

13

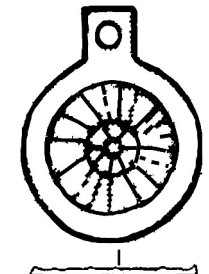

14

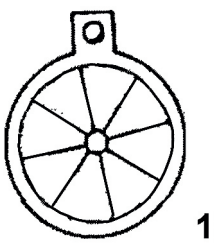

15
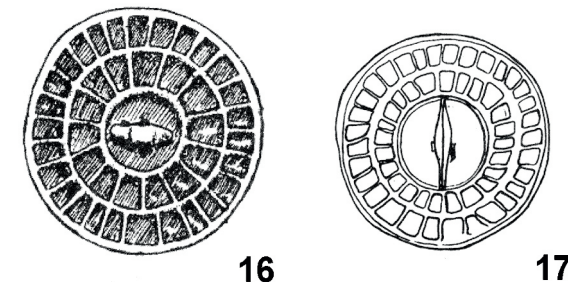

17
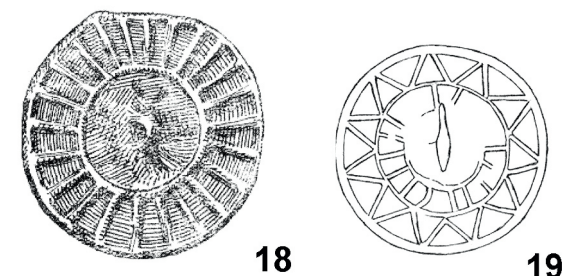

Рис. 1. Китайские зеркала (1-б) и позднесарматские копии (подражания):

1 - зеркало из Аньяна [Ван Чэньи, 2011, с. 80, рис. 1, с. 111]; 2 - ханьское зеркало [Ван Чэньи, 2011, рис. 32];

3 - зеркало эпохи Шан из Чэньду [Ван Ганхуай, 2015, с. 63]; 4 - зеркало эпохи Чжаньго [Ван Ганхуай, 2015, с. 142];

5 - зеркало эпохи Чжаньго [Ван Ганхуай, 2015, с. 102]; 6 - зеркало эпохи Чжаньго [Ван Ганхуай, 2015, с. 158];

7 - Ольвия [Драчук, 1975, табл. XVIII,I]; 8 - Нижнегниловский могильник [Гугуев, Трейстер, 1995, рис. 4,1];

9, 12, 13 - некрополь Кобякова городища [Косяненко, 1994, рис. 23, 24; Гугуев, Трейстер, 1995, рис. 4,4];

10 - некрополь Тирамбы [Гугуев, Трейстер, 1995, рис. 4,2]; 11 - могильник у хут. Чернышев [Гугуев, Трейстер, 1995, рис. 4,3]; 14, 15 - Неаполь Скифский [Драчук, 1975, табл. XVI,34, XVII,9],

16-19 - Паласа-сыртский могильник [Малашев и др., 2015, рис. 202,3,6,11,14]

Fig. 1. Chinese mirrors (1-6) and Late Sarmatian copies (imitations):

1 - mirror of Anyang; 2 - mirror of the Han period; 3 - mirror of the Shan period;

4-6- mirrors of the period Warring States; 7 - Olvia; 8 - Nizhnegnilovsky burial mound;

9, 12,13 - the necropolis of Kobyakovo; 10 - necropolis of Tiramba; 11 - burial mound near the Chernyshev village;

14, 15 - Naples Scythian; 16-19 - Palasa-Syrt burial mound 

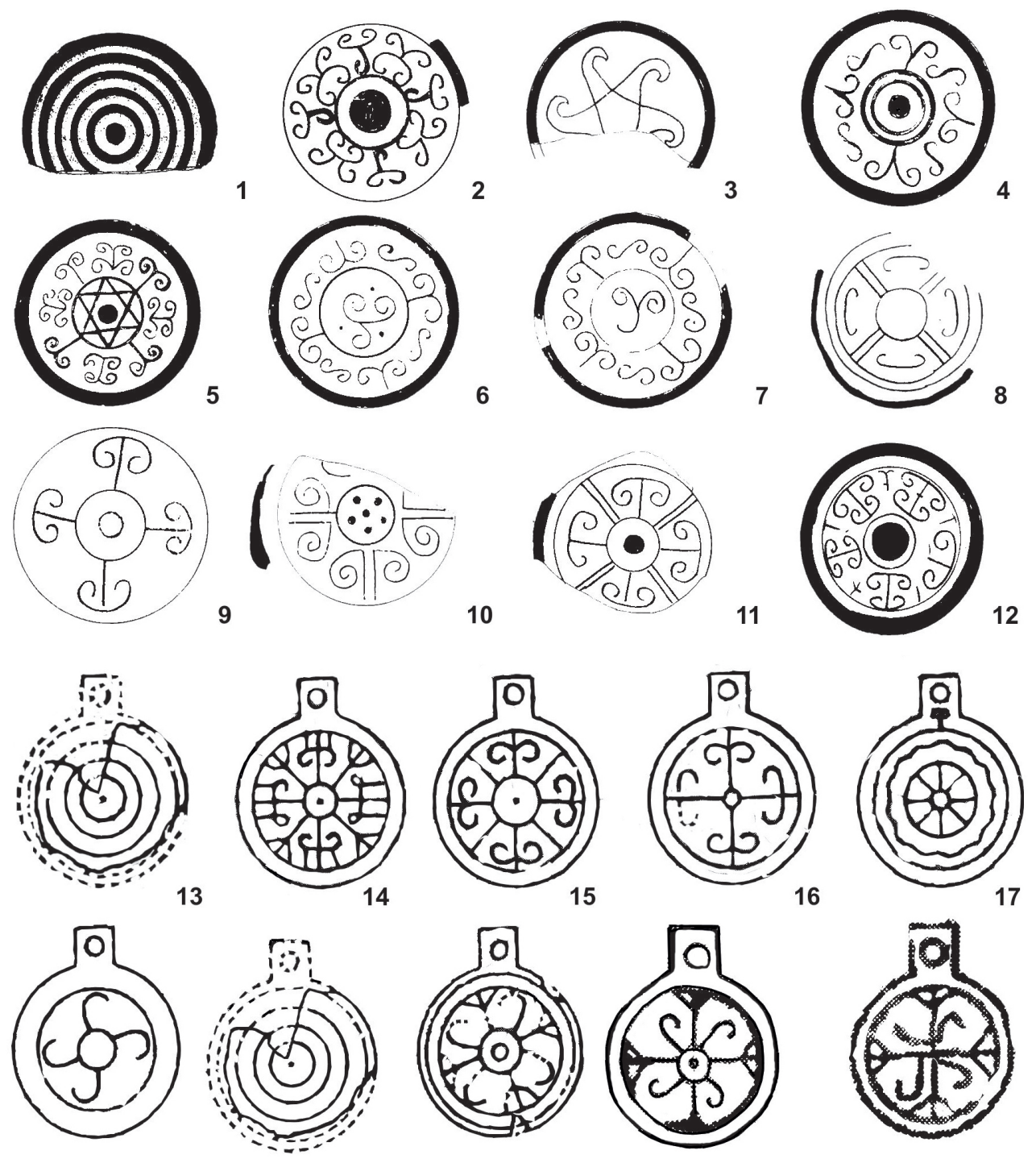

18

19

20

21
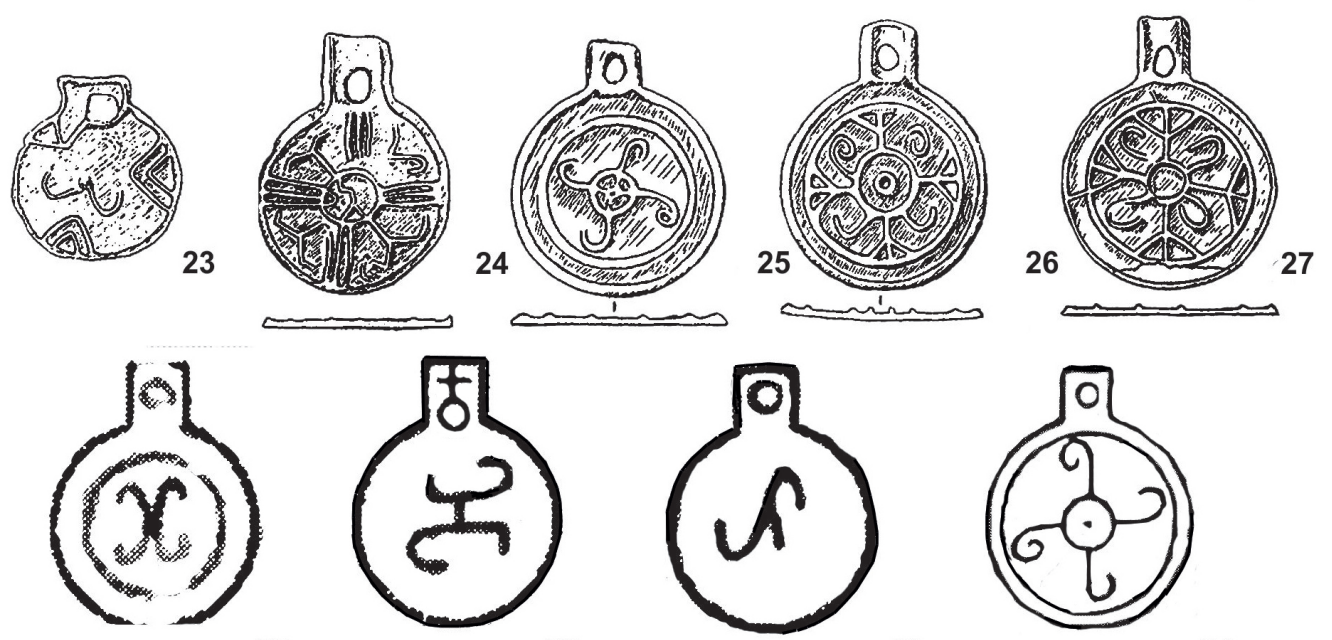

28

29
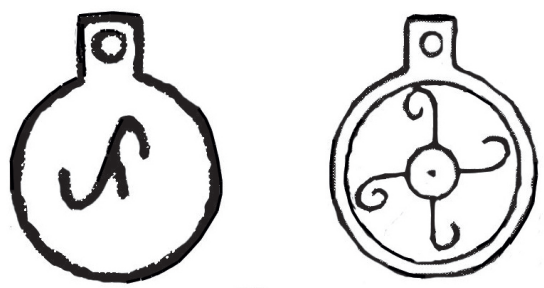

30

31

Рис. 2. Орнаменты на ханьской черепице с территории Внутренней Монголии (1-12) [Чэнь Юнчжи, 2003, c. $5,6,8,12,13]$ и на бронзовых зеркалах-подвесках с территории Подонья и Северного Причерноморья (13-31) [Драчук, 1975, табл. XVI, XVII; Косяненко, 1994, рис. 23, 24; Гугуев, Трейстер, 1995, рис. 4,5]

Fig. 2. Ornaments on Han shingles from the territory of Inner Mongolia (1-12) and on bronze mirror-pendants from the territory of the Don region and the Northern Black Sea Coast (13-31) 

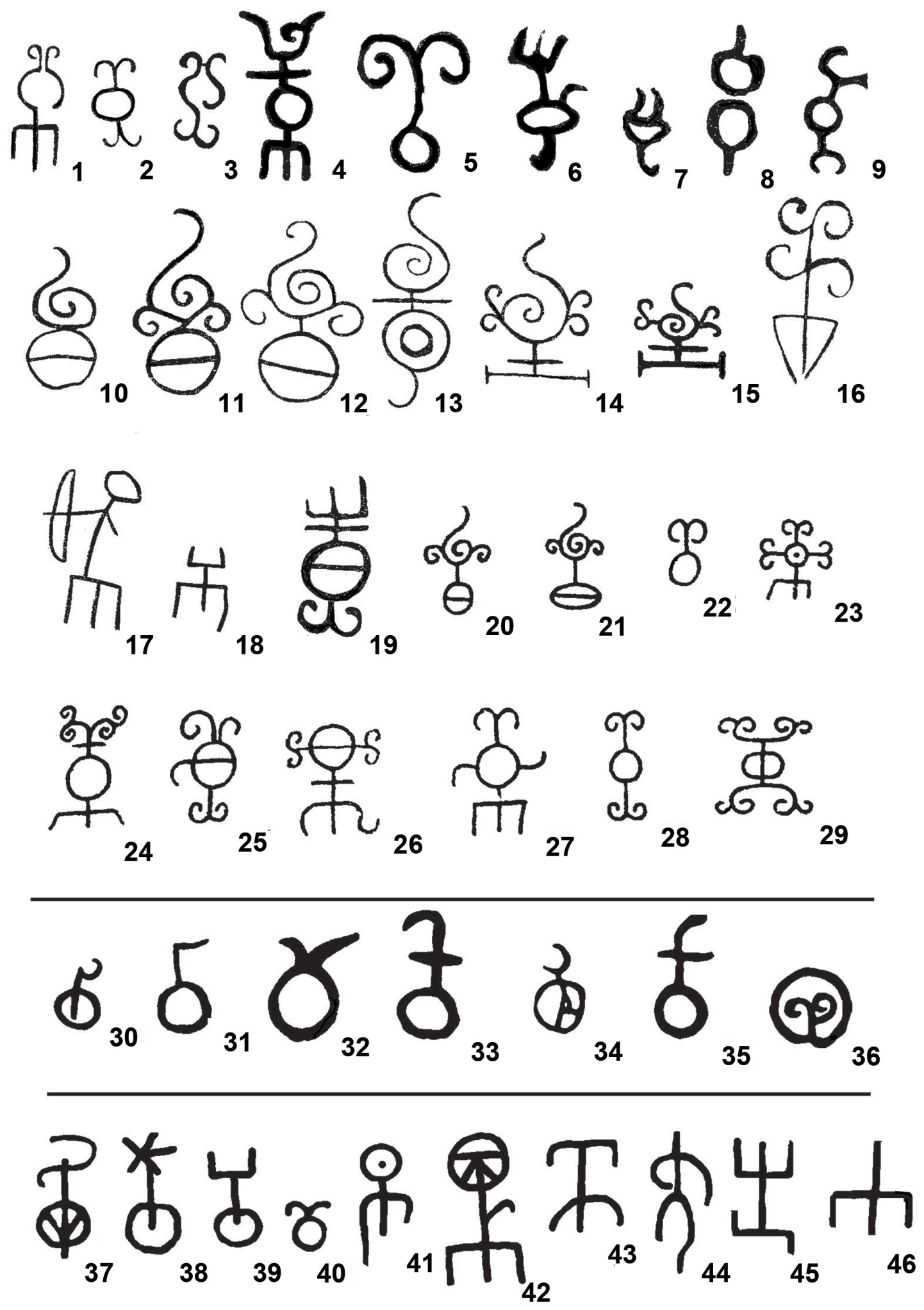

Рис. 3. Тамги хуннского времени в скоплениях петроглифов:

1-29 - Цагаан-Гол, Монголия [Новгородова, 1984, рис. 53, 56]; 30-33 - Рашаан Хад, Монголия [Пэрлээ, 1976, № 86, 221, 28, 16]; 34-36 - Дундэндэг-газар, Монголия [Пэрлээ, 1976, № 40, 19, 79];

37-46 - Сяньцзитань, пункты № 1-5, пров. Фуцзянь, Китай [Shanlin Gai, Yudong Lou, 1993, pic. 185, 186]

Fig. 3. Tamgas of the Xiongnu time in collections of petroglyphs:

1-29 -Tsagaan-Gol, Mongolia; 30-33 - Rashaan Had, Mongolia; 34-36 -Dundendag-gazar, Mongolia;

37-46-Xianjitang, points no. 1-5, Fujian Province, China 

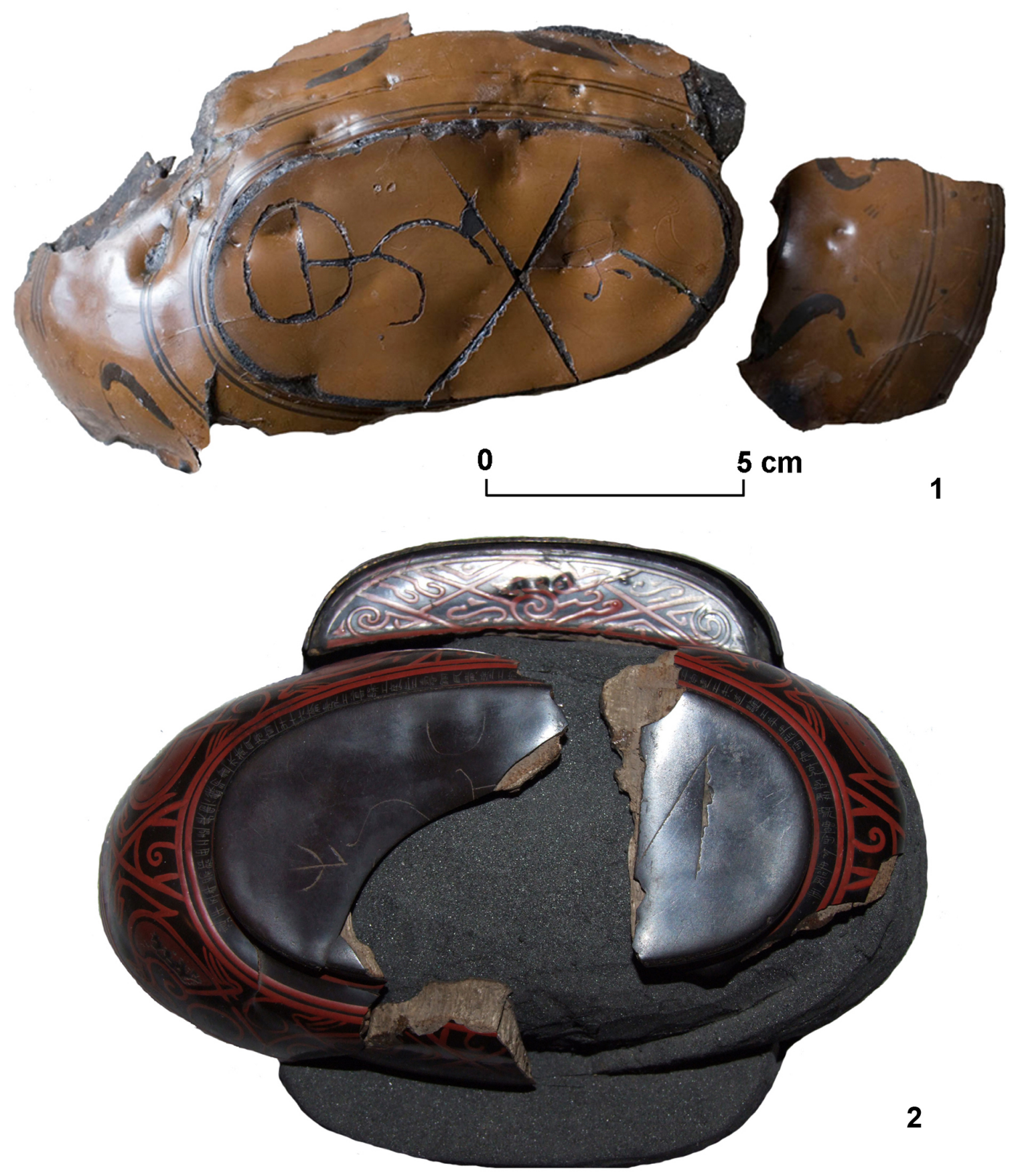

Рис. 4. Лаковые чашечки «бэй» с тамгообразными знаками, Ноин-Ула, Монголия: 1 - могильник Суцзуктэ, курган № 20; 2 - могильник Цзурумтэ, раскопки А.Д. Симукова 1927 г.

Fig. 4. Lacquer cups "bei” with tamga-like signs, Noin-Ula, Mongolia:

1 - Burial mound Sudzukte, mound 20; 2 - Burial mound Tzurumte, excavations of A.D. Simukov, 1927 


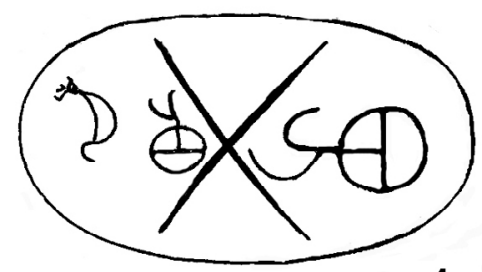

1

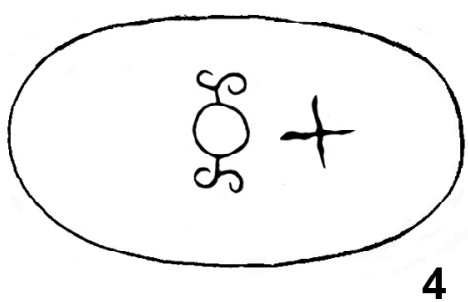

4

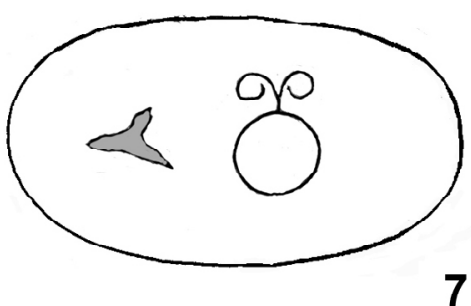

7

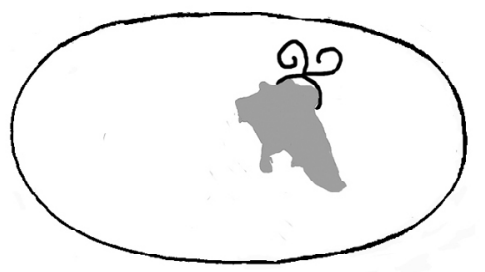

10

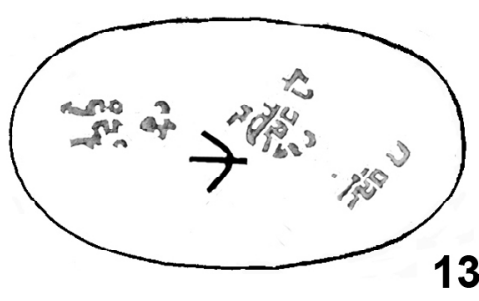

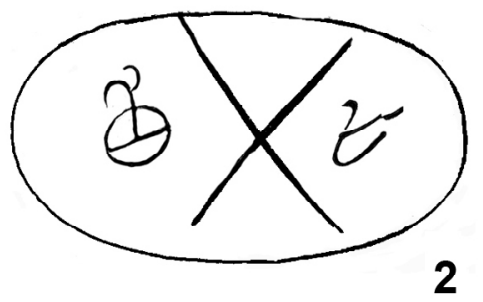

2

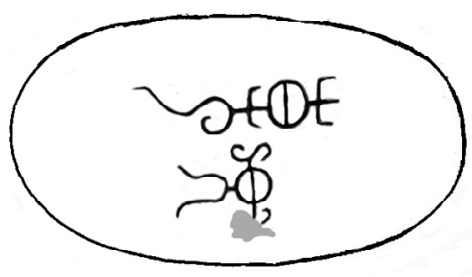

5

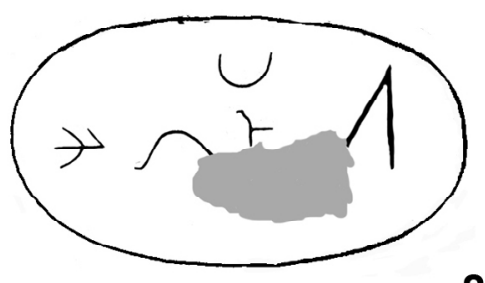

8

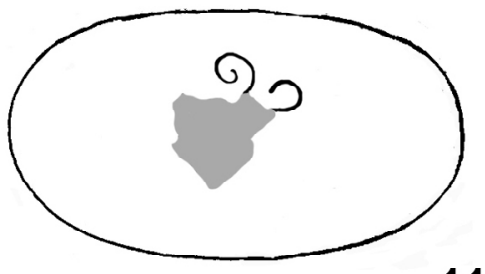

11

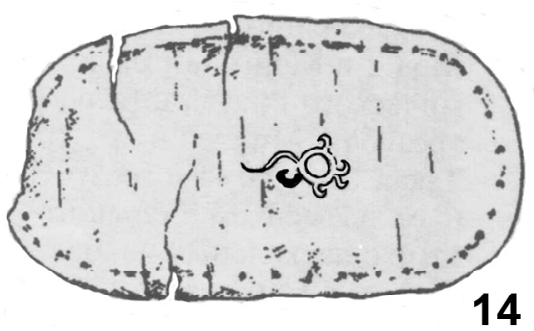

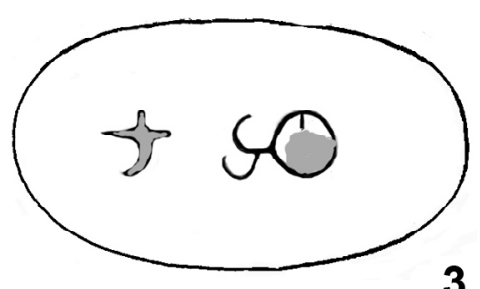

3

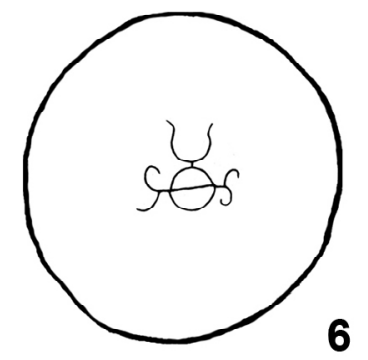

6

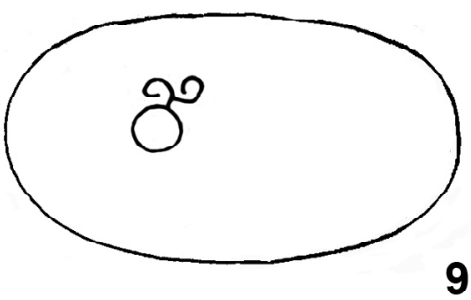

9

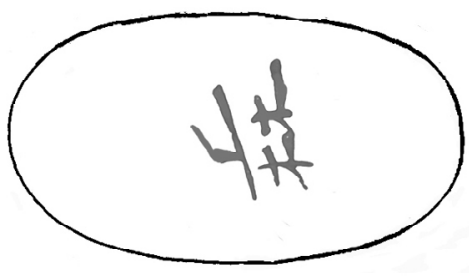

bet

12

\section{$12 a$}

Рис. 5. Тамгообразные знаки на донышках лаковых чашек (1-5, 7-13), донышке плошки (6), на ручке лаковой чашки (12a) и на донышке берестяного туеска (14):

1-3 - Ноин-Ула, Суцзуктэ, курган № 20; 4-6 - Ноин-Ула, Суцзуктэ, курган № 31; 7, 9-11 - Ноин-Ула, Суцзуктэ, курган № 23 [Елихина, Новикова, 2013, рис. 1]; 8 - Ноин-Ула, Цзурумтэ, раскопки Симукова 1927 г.;

12, $12 a$ - Ноин-Ула, Суцзуктэ, курган № 6 [Pirazzoli-t’Serstevens, 2009, fig. A-1-5];

13 - Сяоцзяцаочан, погребение № 26, провинция Хубэй, Китай [Краткое сообщение..., 1999, рис. 30,2];

14 - Царам, курган № 7, Бурятия [Миняев, Сахаровская, 2007, рис. 3,3]

Fig. 5. Tamga-like signs on the bottoms of the lacquer cups $(1-5,7-13)$, on the bottom of the plate (6), on the handle of the lacquer cup (12a) and on the bottom of the birchbark (14):

1-3 - Noin-Ula, Sudzukte, mound 20; 4-6 - Noin-Ula, Sudzukte, mound 31; 7, 9-11 - Noin-Ula, Sudzukte, mound 23; 8 - Noin-Ula, Tzurumte, excavations of A.D. Simukov, 1927; 12, $12 a$ - Noin-Ula, Sudzukte, mound 6;

13 - Xiaojiaceochang, burial 26, Hubei Province, China; 14 - Tsaram, burial 7, Buryatia 

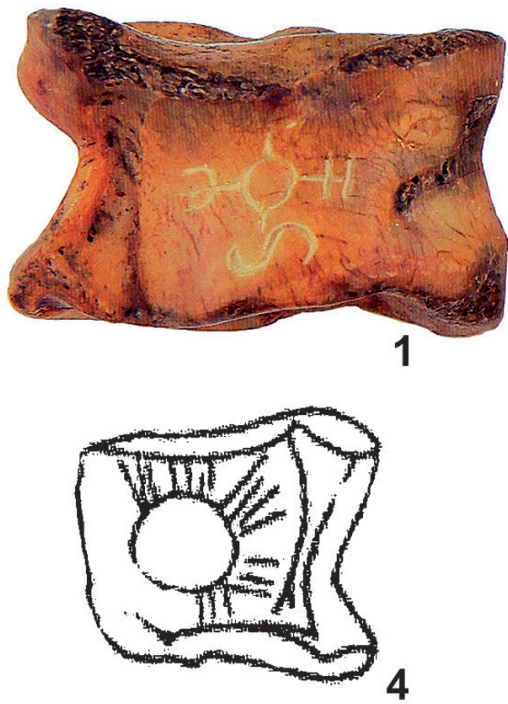

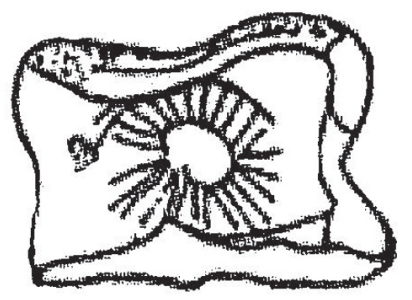

2

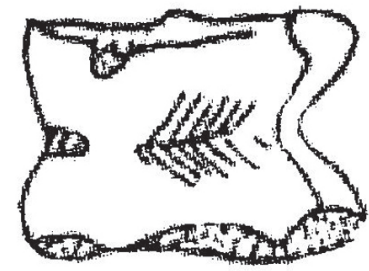

3
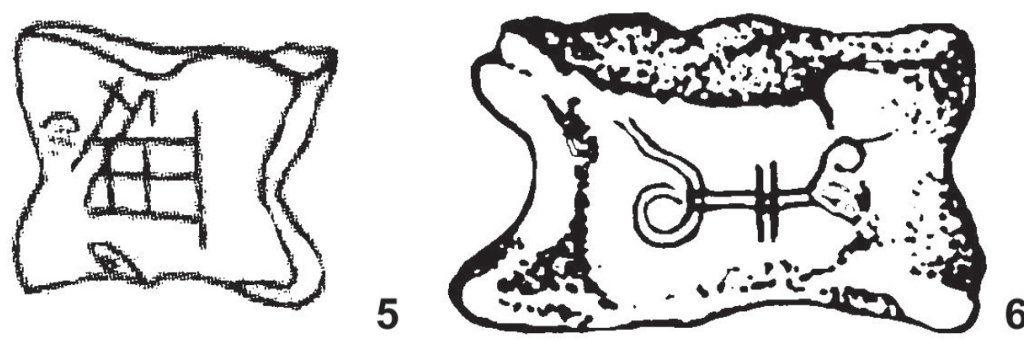

Рис. 6. Тамгообразные знаки на астрагалах:

1-5 - могильник Гол-Мод 2, могила № 3, Монголия [Эрдэнэбаатар и др., 2015, рис. 35-36];

6 - поселение Средние Дурены, жилищный комплекс 5, Бурятия [Давыдова, Миняев, 2003, табл. 96,2]

Fig. 6. Tamga-like signs on astragalus:

1-5 - Burial mound Gol-Mod 2, tomb 3, Mongolia; 6 - settlement of Middle Duren, housing complex 5, Buryatia 


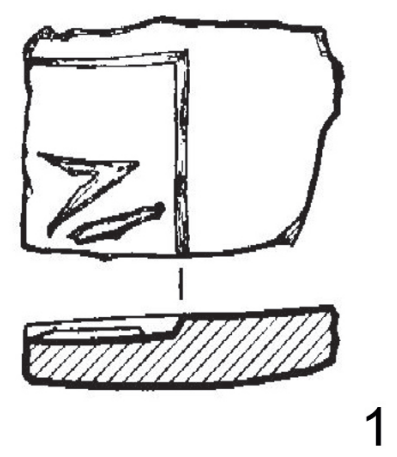

1
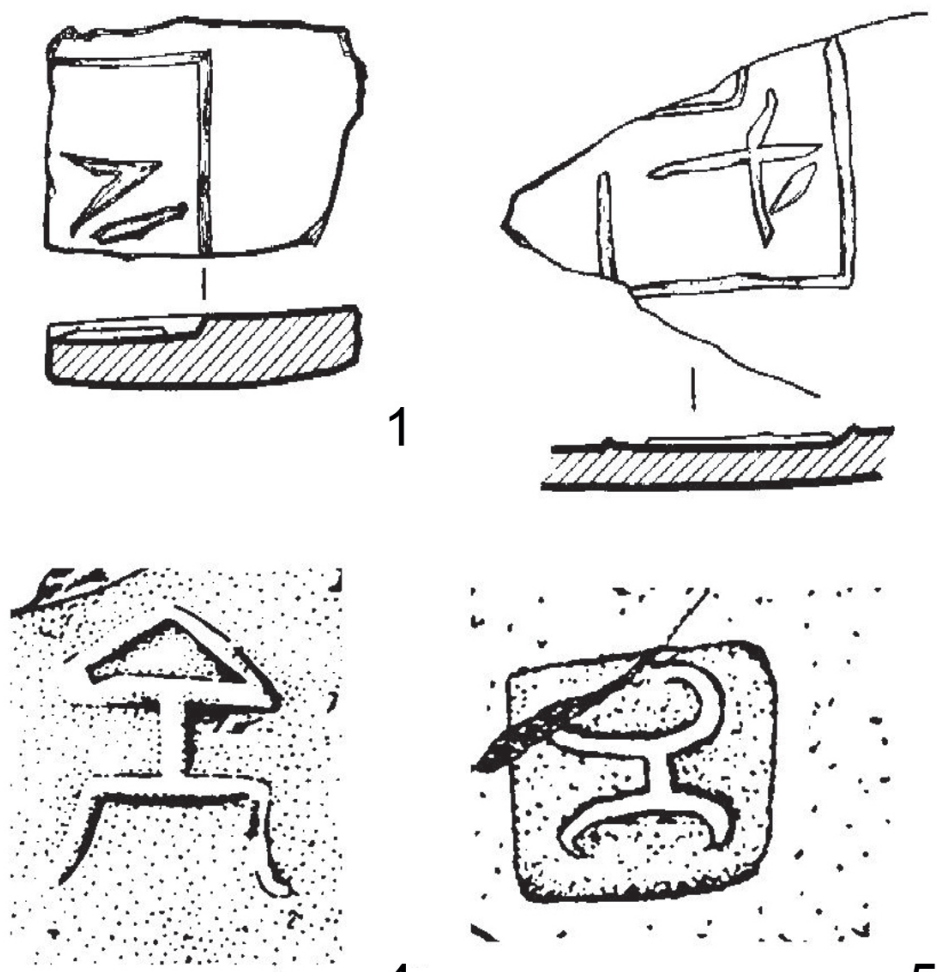

4

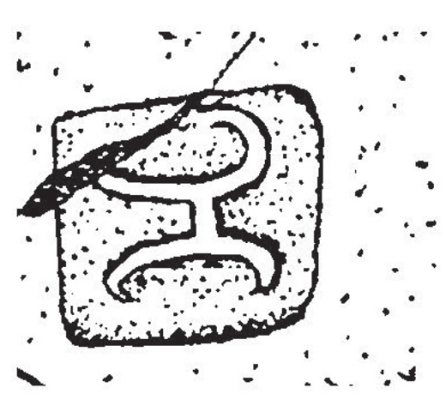

5

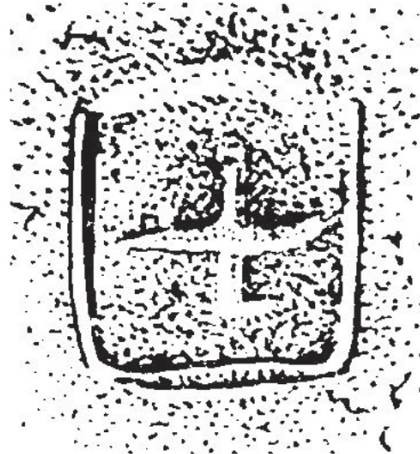

2

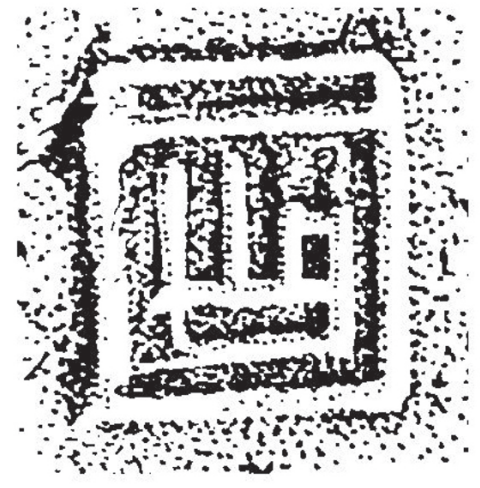

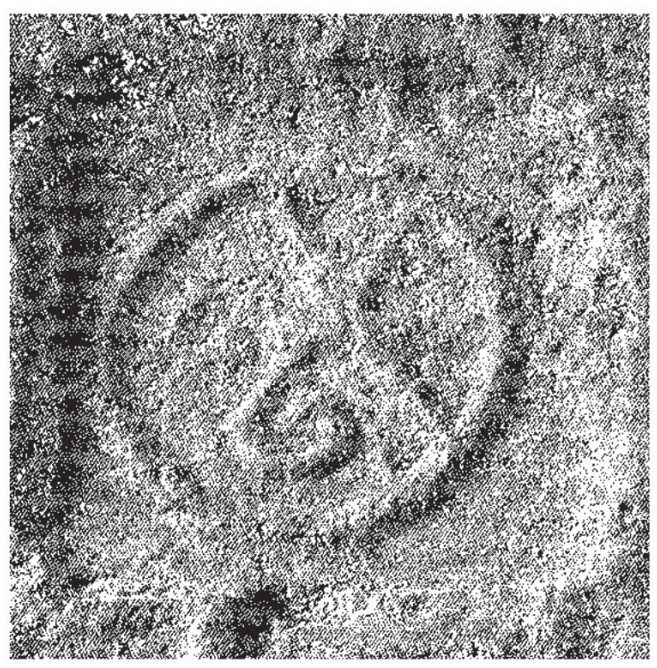

7

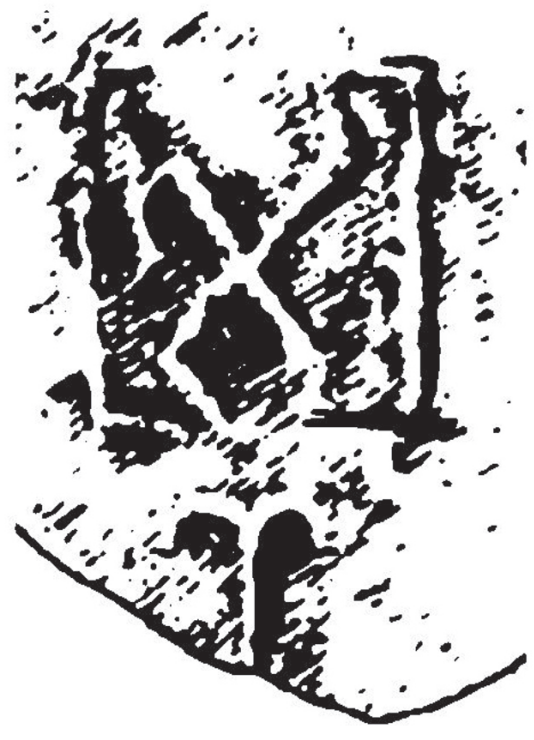

Рис. 7. Тамгообразные знаки на донышках керамических сосудов:

1, 2 - Ноин-Ула, Суцзуктэ, курган № 6 [Umehara, 1960, pic. 227];

3, 4, 6 - Иволгинское городище, Забайкалье [Руденко, 1962, рис. 52; Давыдова, 1995, с. 28]; 5 - поселение Нижние Дурены, Забайкалье [Давыдова, Миняев, 2003, табл. 21,5];

7 - могила № 2 могильника Дуурлиг-Нарс, Монголия [Хуннский могильник Дуурлиг-Нарс..., 2009, p. 66]; 8 - погребение № 210, Иволгинский могильник, Забайкалье [Давыдова, 1996, с. 74]

Fig. 7. Tamga-like signs on the bottoms of ceramic vessels:

1, 2 - Noin-Ula, Sudzukte, mound 6; 3, 4,6- Ivolginsky hillfort, Transbaikal;

5 - settlement of the Lower Duren, Transbaikal; 7 - tomb 2, burial mound Duurlig Nars, Mongolia; 8 - burial 210, burial mound Ivolginsky, Transbaikal 
E.S. Bogdanov. The Origin of the Tamgas of the Xiongnu
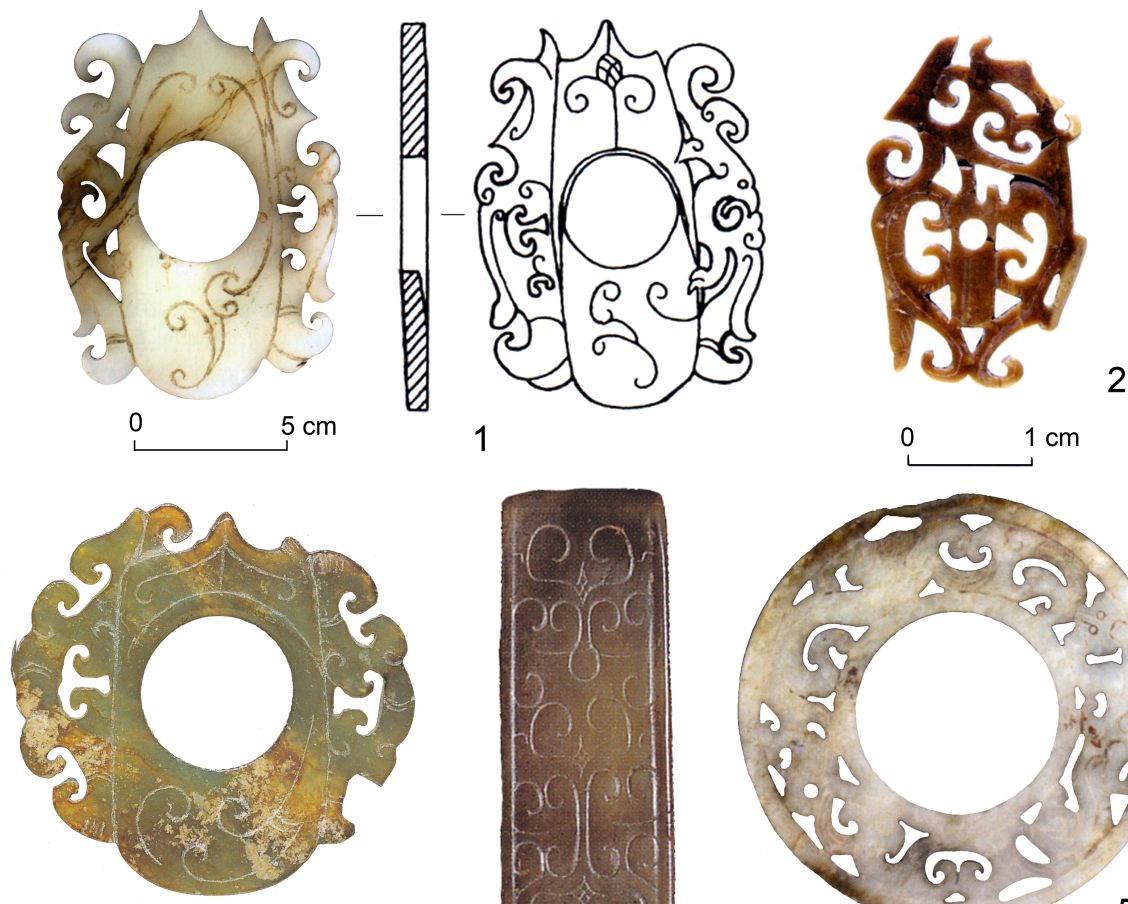

0 $5 \mathrm{~cm}$

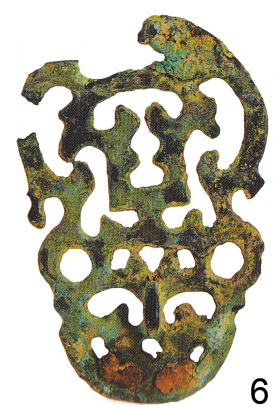

6

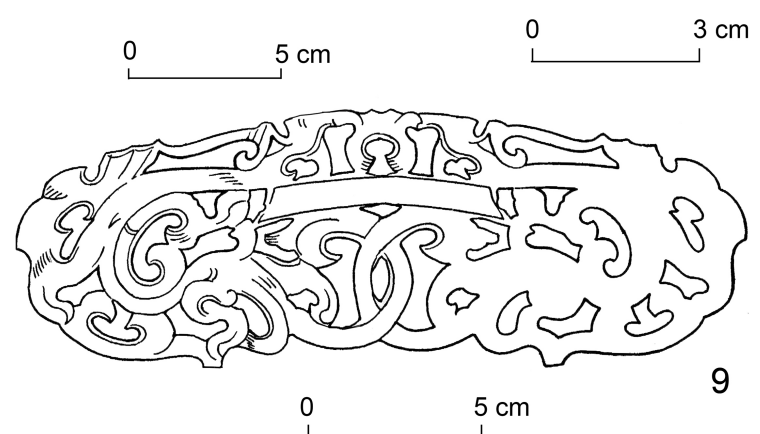

0 $5 \mathrm{~cm}$
1

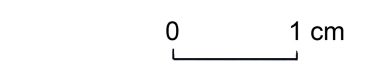

2
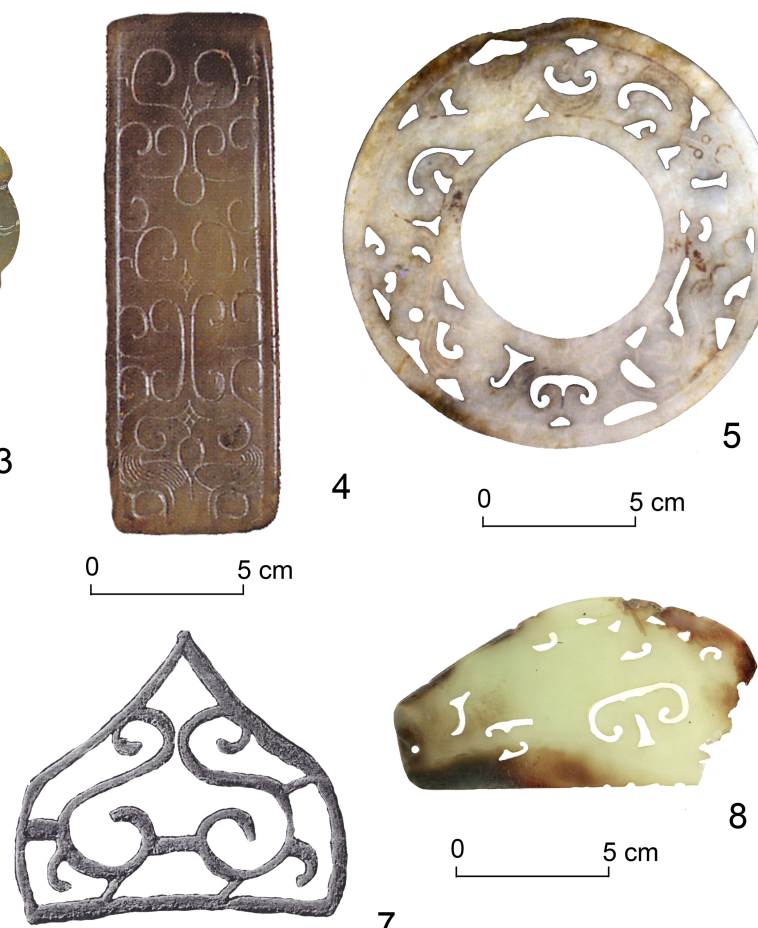

7

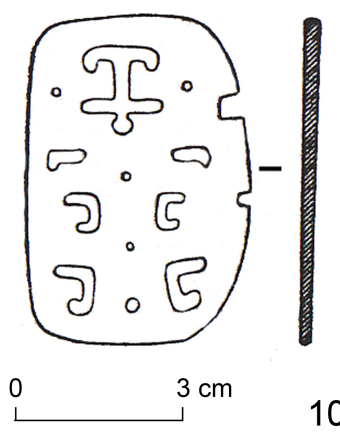

Рис. 8. Нефритовые и бронзовые пластины с прорезным ажурным орнаментом:

1, 5 - ханьское погребение в провинции Цзянсу, Китай [Ханьское погребение..., 2007, рис. 30, 34];

2 - могила № 2 могильника Дуурлиг-Нарс, Монголия [Хуннский могильник Дуурлиг-Нарс..., 2009, р. 62];

3, 4 - погр. 194, 200, Лолан, Наньшань, Корея [The ancient..., 2001, pic. 123; 27:4]; 6 - погребение № 1, могильник Дундшандын, Монголия [Treasures..., 2011, fig. 168]; 7 - случайная находка из разрушенного ханьского погребения, провинция Ганьсу, Китай [Ли Сяоцин, Нань Баошэн, 2003, pic. 13, 14]; 8 - Ноин-Ула, Суцзуктэ, курган № 31; 9 - Ноин-Ула, Суцзуктэ, курган № 24 [Руденко, 1962, табл. XLVI, 1]; 10 - погребение № 3, памятник Яоцзяган, провинции Хубэй, Китай [Краткий отчет..., 1988, с. 167, рис. 12,1]

Fig. 8. Jade and bronze plates with a slotted openwork ornament:

1, 5 - Han burial in Jiangsu Province, China; 2 - tomb 2, burial mound Duurlig Nars;

3, 4 - burial 194, 200, Lolan, Nanshan, Korea; 6 - burial 1, burial mound Duurlig Nars, Mongolia;

7 - casual find from the destroyed Han burial, Gansu Province, China; 8 - Noin-Ula, Sudzukte, mound 31; 9 - Noin-Ula, Sudzukte, mound 24; 10 - burial 3, Yaojigang monument, Hubei Province, China 

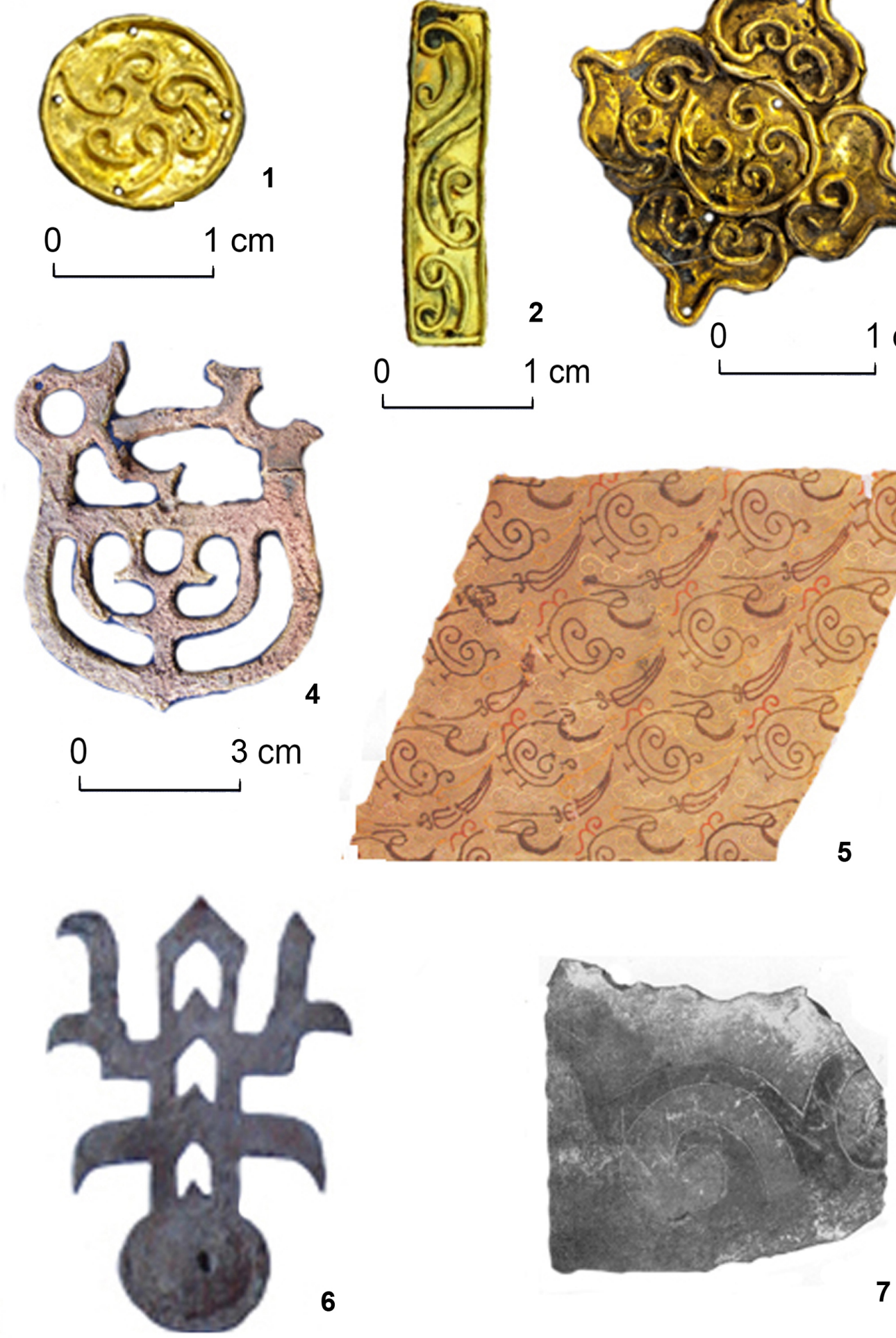

7

Рис. 9. Предметы китайского производства с облачным (ажурным) орнаментом:

1-3 - золотые нашивные бляшки, курган № 22, Ноин-Ула, Суцзуктэ; 4 - бронзовая пряжка, курган № 20, Ноин-Ула, Суцзуктэ; 5 - фрагмент шелковой ткани с вышивкой, курган № 1, Ноин-Ула, Суцзуктэ [Treasures..., 2011, fig. 395]; 6 - бронзовое навершие, случайная находка, провинция Шэньси, Китай [Imperial China..., 2000,

fig. 33]; 7 - фрагмент глиняного сосуда, поселение у с. Дурены, Забайкалье [Руденко, 1962, табл. XXVII,6]

Fig. 9. Items of Chinese manufacture with a cloudy (openwork) ornament:

1-3 - golden sewing plaques, mound 22, Noin-Ula, Sudzukte; 4 - bronze buckle, mound 20, Noin-Ula, Sudzukte;

5 - fragment of silk fabric with embroidery, mound 1, Noin-Ula, Sudzukte; 6 - bronze pommel, casual find, Shaanxi Province, China; 7 - fragment of ceramic vessel, settlement near Durens village, Transbaikal 

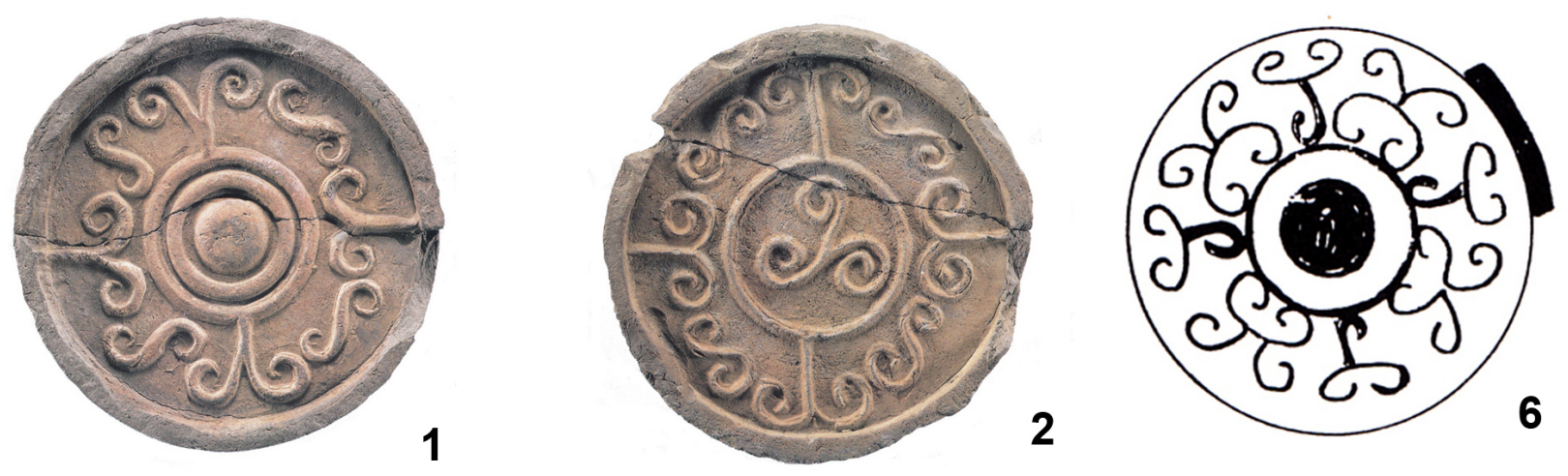

\section{1}

2
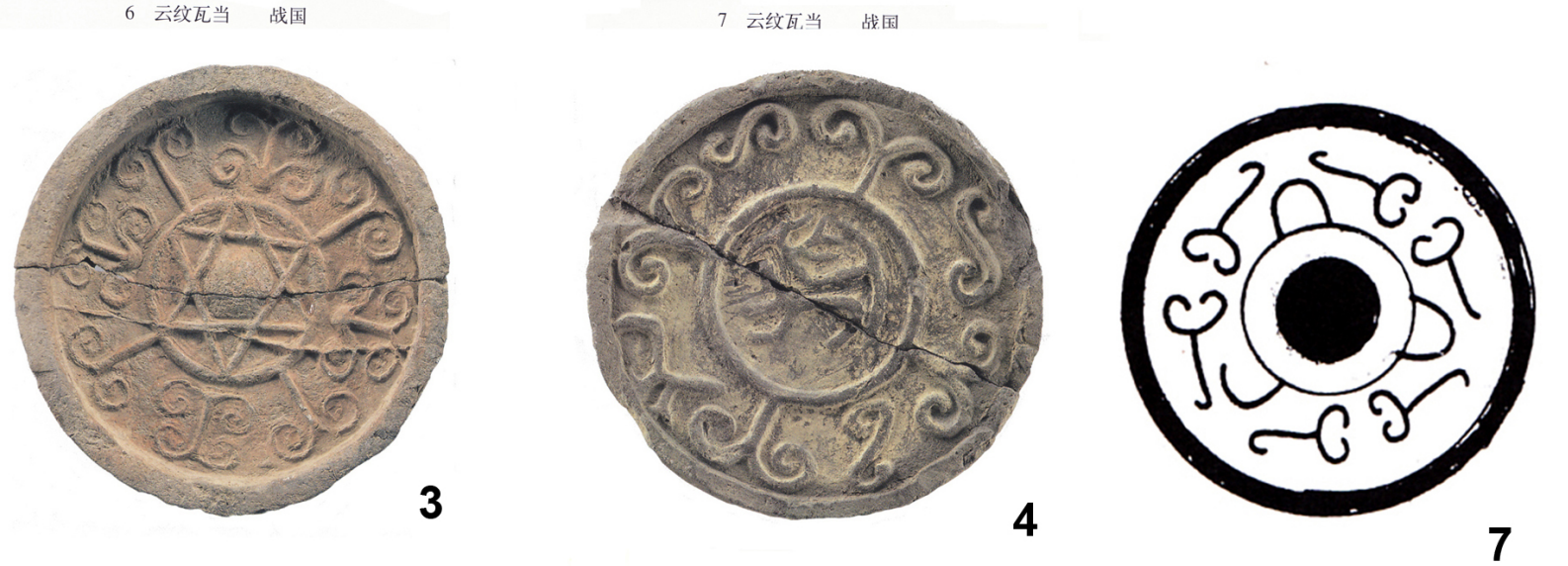

4
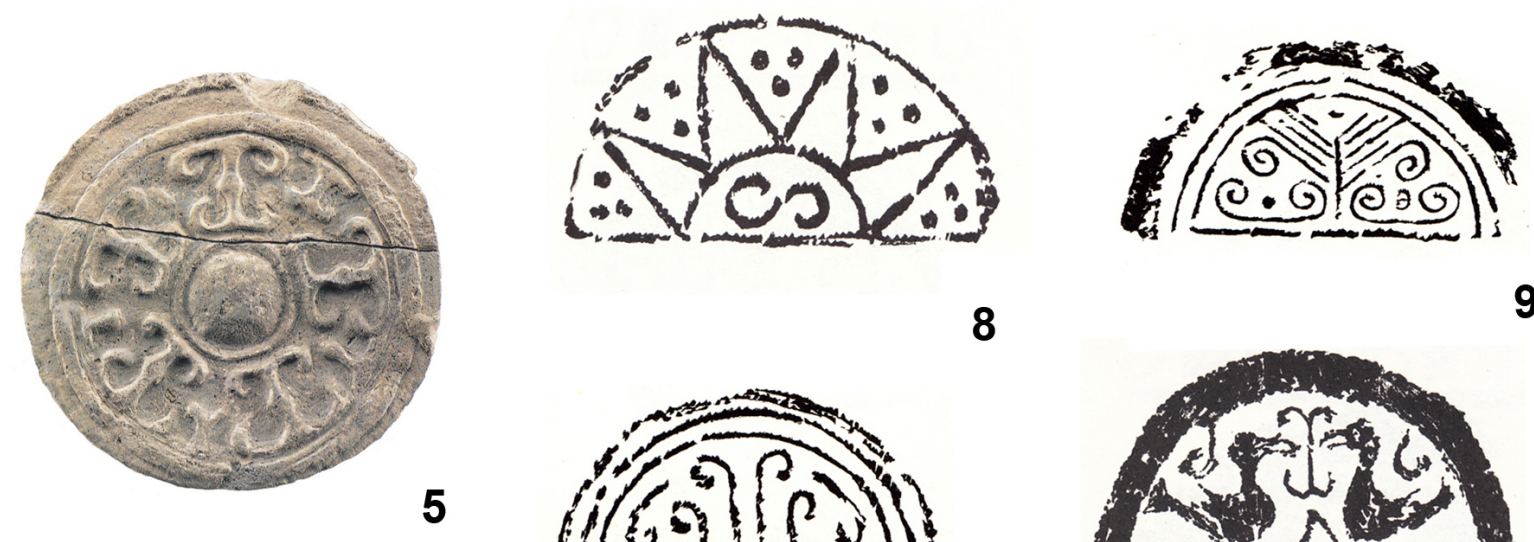

8

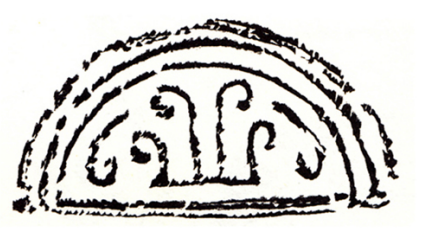

10

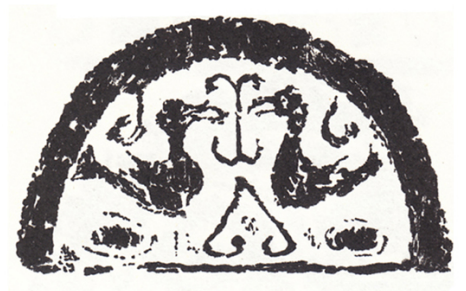

11

Рис. 10. Концевые диски (черепица) из Внутренней Монголии эпохи Чжаньго и Хань с облачным (ажурным) орнаментом [Чэнь Юнчжи, 2003, кат. 12-14, 22, 30, 75, с. 6, ил. 20, 21; Полное собрание..., 2009, с. 123 , ил. 6 , с. 126 , ил. 4, 7, 8]

Fig. 10. End discs (shingles) from Inner Mongolia of the periods Warring States and Han with cloudy (openwork) ornament 


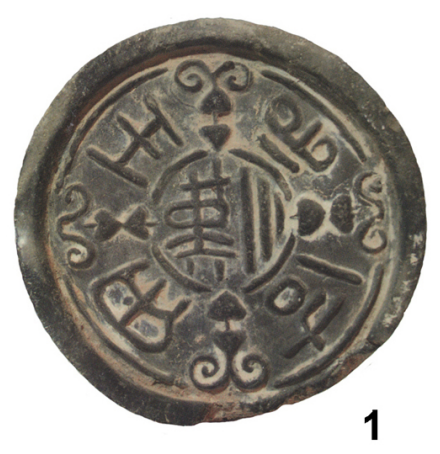

米

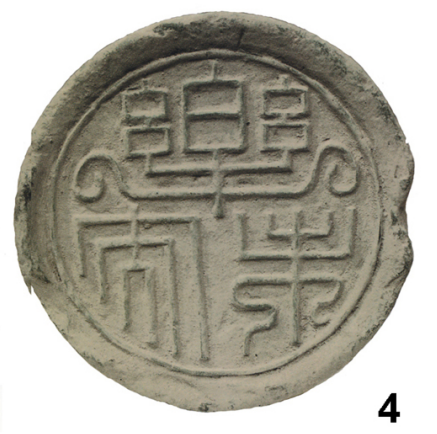

4
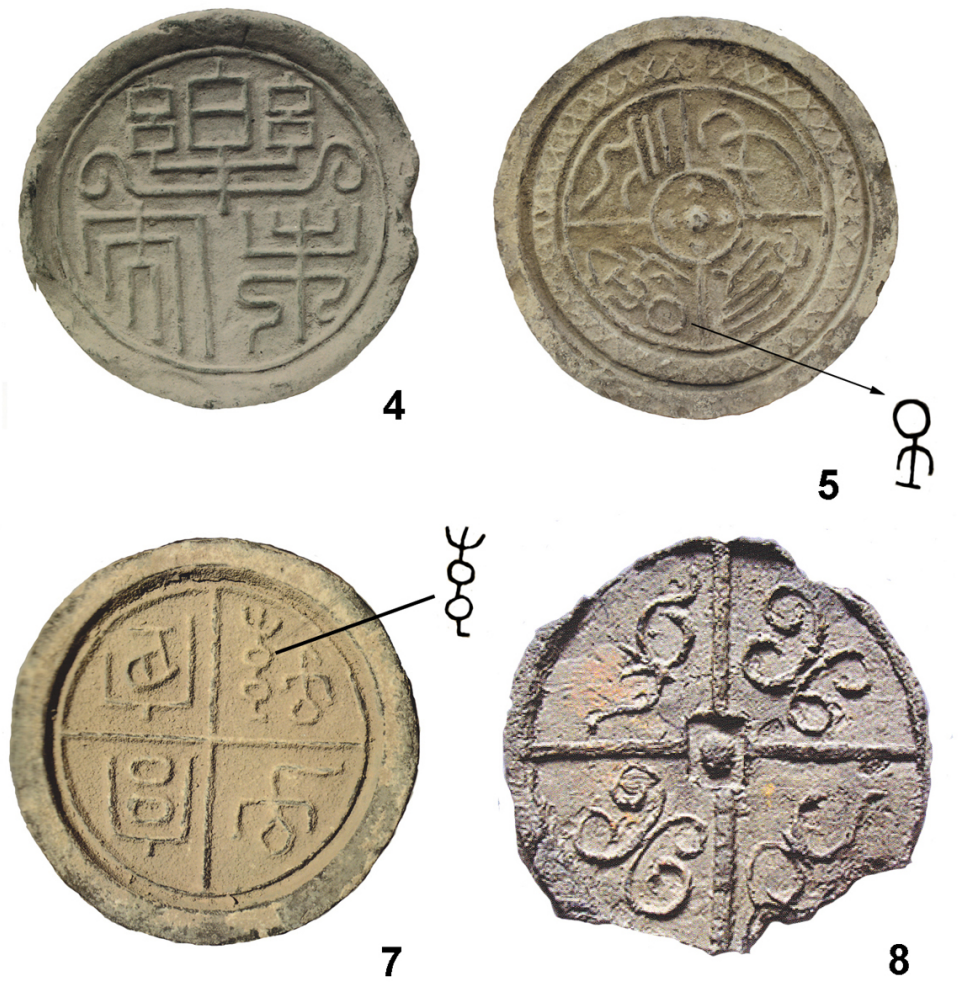

7

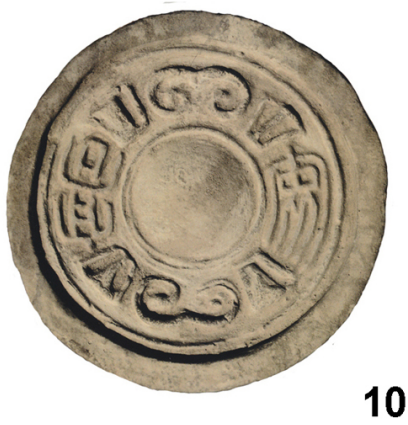

10

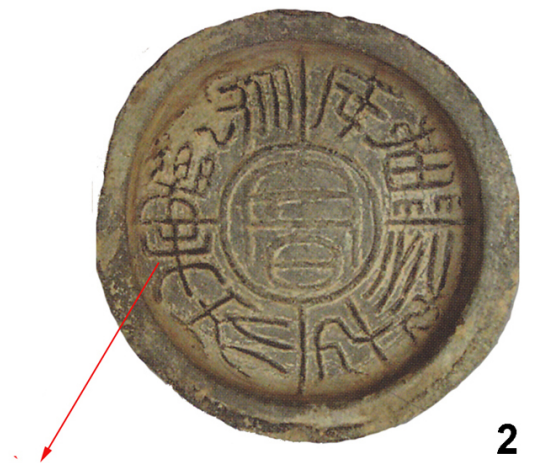

2

8

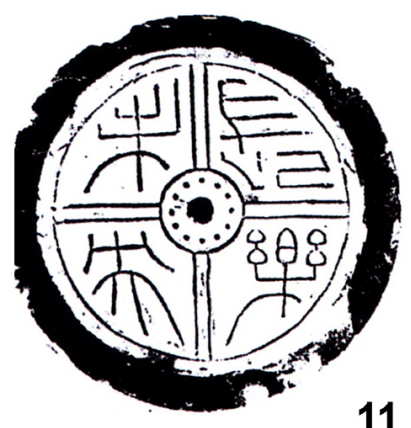

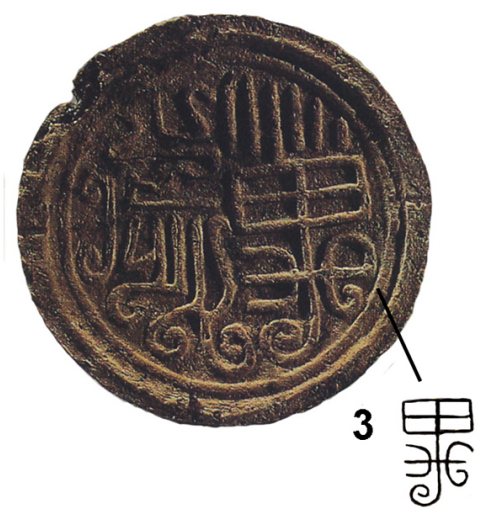
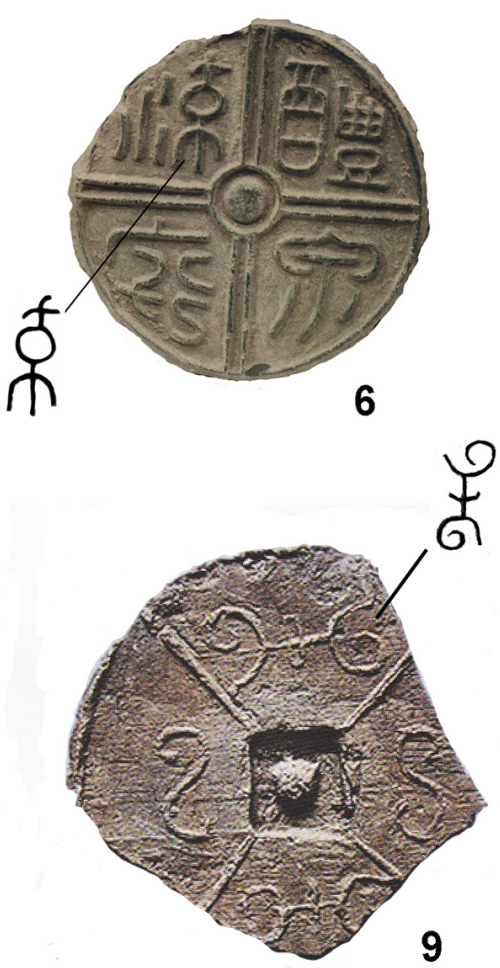

11

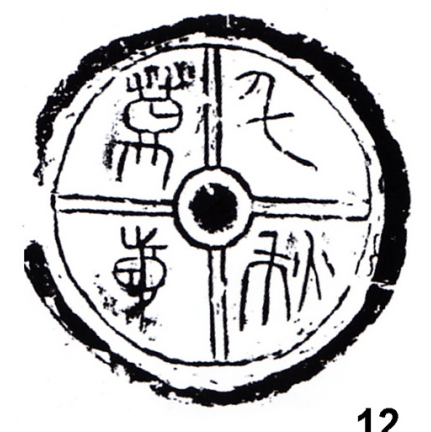

12

Рис. 11. Концевые диски (черепица) эпохи Чжаньго и Хань с иероглифическими надписями:

1-7, 10 - Внутренняя Монголия [Го Бин, 2010, ил. 14, 4, 6, 10, 11, 13, 14, 18]; 8, 9 - городище Тэрэлжин Дэрэвэлжин, Монголия [Treasures..., 2011, p. 79, pic. 67]; 11, 12 - Внутренняя Монголия [Wei Jie, 2008, p. 98, pic. 5, 12]

Fig. 11. End discs (shingles) of the periods Warring States and Han with hieroglyphic inscriptions: 1-7, 10-12 - Inner Mongolia; 8, 9- Terelzhin Derevalzhin hillfort, Mongolia 

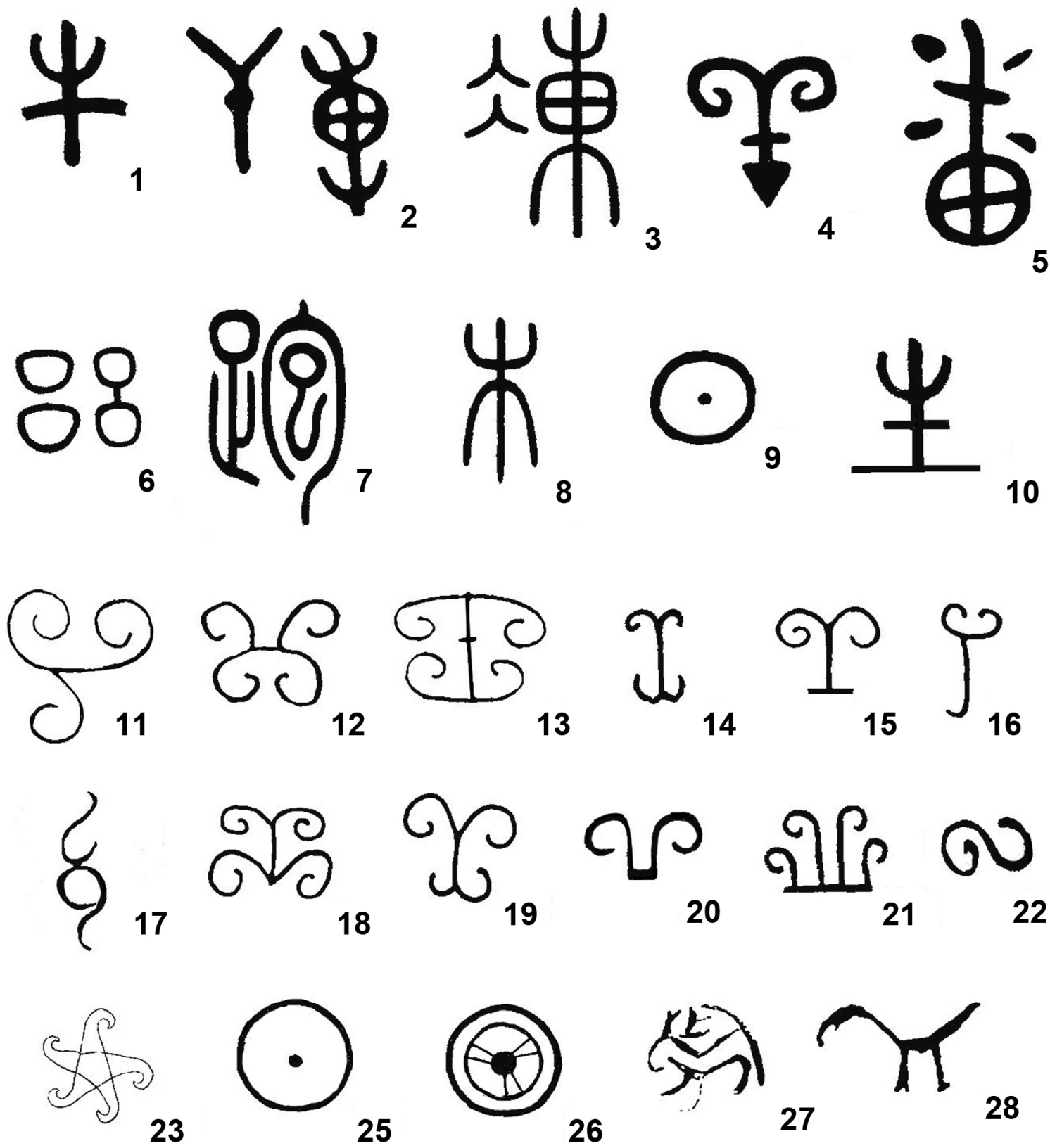

27

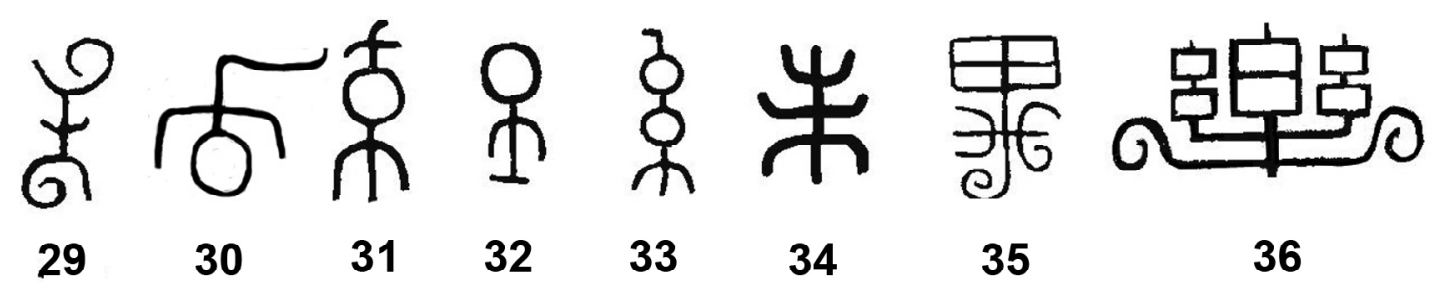

Рис. 12. Китайские идеографы на ханьской черепице [Объяснение..., 2010, с. 17, 36, 81, 92, 221, 265 ; Чэнь Юнчжи, 2003; Го Бин, 2010]

Fig. 12. Chinese ideographs on Han shingles 


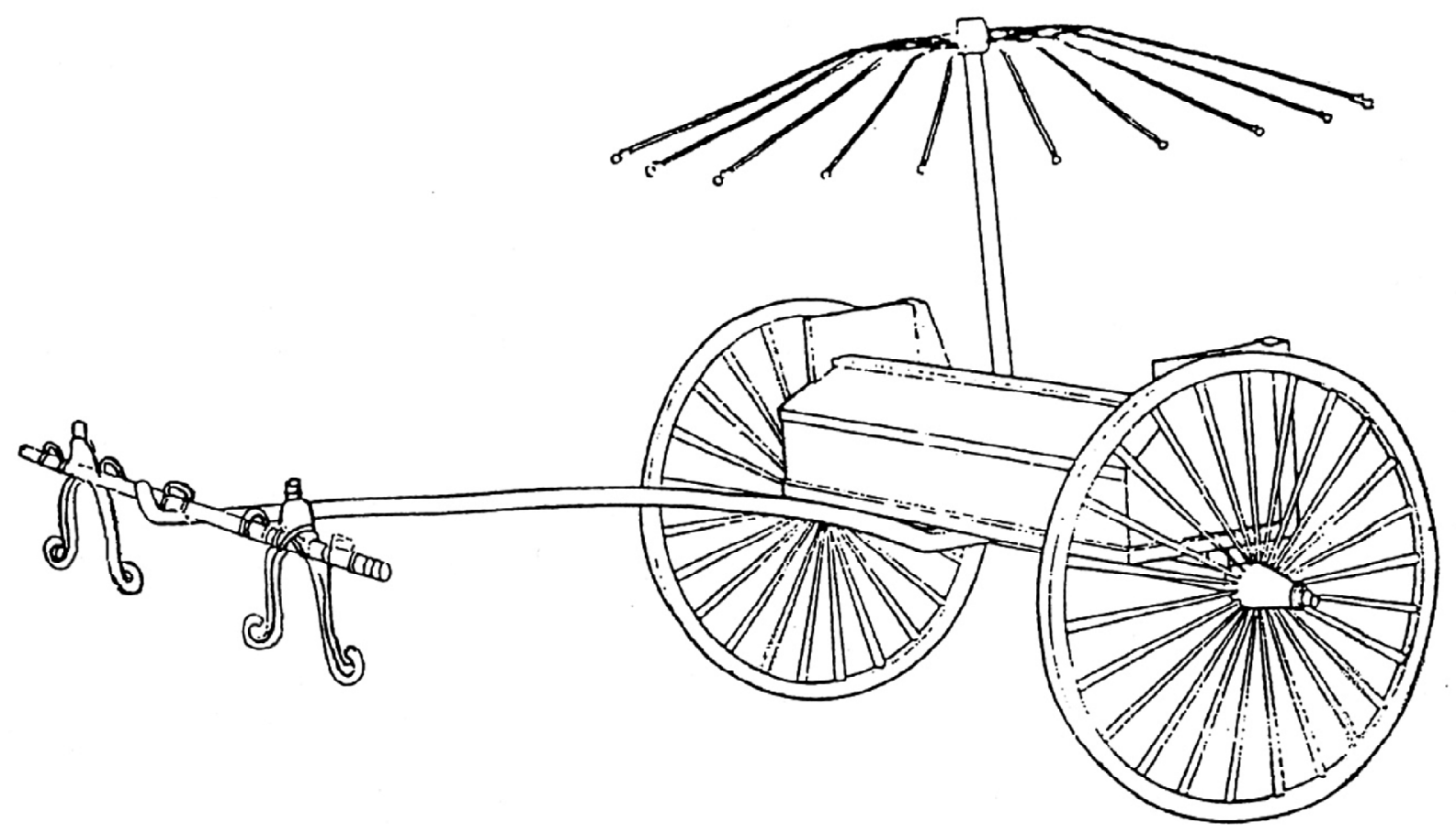

Рис. 13. Китайская колесница

Fig. 13. The Chinese chariot 


\section{ПРИМЕЧАНИЯ}

${ }^{1}$ Подобные метки С.А. Яценко на черепице из развалин ханьского дворца в Хакасии ошибочно считает «хуннскими тамгами» [Яценко, 2001, с. 105]. Сравнительный анализ материалов с территории Китая позволяет утверждать, что это метки самих мастеров, - изготовителей предметов.

2 Здесь и далее перевод с китайского выполнен М. Угроватовой.

${ }^{3}$ Автор выражает огромную благодарность С.В. Алкину за помощь при работе с китайскими материалами.

\section{СПИСОК ЛИТЕРАТУРЫ}

Барцева Т. Б., 1971. Предварительные результаты спектрального изучения зеркал-подвесок Центрального Кавказа // История и культура Восточной Европы. Тр. ГИМ. М. : Гос. ист. музей. С. 133-138.

Безруков А. В., 2000. Сарматы Южного Приуралья и Нижнего Поволжья на Великом Шелковом пути // Проблемы истории, филологии, культуры. Вып. IX. М. ; Магнитогорск : Изд-во Магнитогор. ун-та. С. 149-155.

Безуглов С. И., Толочко И. В., 2006. О культурноисторических связях населения Танаиса в эпоху переселения народов (по материалам погребений) // Древности Боспора : сб. науч. ст. Вып. 10. М. : Ин-т археологии РАН. С. 89-110.

Богданов Е. С., 2006. Образ хищника в пластическом искусстве кочевых народов Центральной Азии (скифо-сибирская художественная традиция). Новосибирск : Изд-во ИАЭТ СО РАН. $240 \mathrm{c}$.

Богданов Е. С., 2009. Искусство хунну: старые концепции, новые факты // «Homo eurasicus» у врат искусства. СПб. : Астерион. С. 212-217.

Боталов С. Г., Гуцалов С. Ю., 2000. Гунно-сарматы урало-казахстанских степей. Челябинск : Рифей. $267 \mathrm{c}$.

Вайнберг Б. И., Новгородова Э. А., 1976. Заметки о знаках и тамгах Монголии // История и культура народов Средней Азии. М. : Наука. С. 6674, 176-179.

Ван Ганхуай, 2015. Ранние китайские зеркала. Шанхай : Шанхай гуцзи чубаньшэ. 199с. (на кит. яз.).

Ван Чэньи, 2011. Собрание лучших зеркал Китая. Чжэньчжоу : Чжунчжоу гуцзи чубаньшэ. 248 с. (на кит. яз.).

Воронятов С. В., 2009. О функции сарматских тамг на сосудах // Гунны, готы и сарматы между Волгой и Дунаем. СПб. : Фак. филологии и искусств СПбГУ. С. 80-98.
Воронятов С. В., 2013. Центральная Азия и Северное Причерноморье: параллели предметов с тамгами // Нижневолжский археологический вестник. Вып. 13. С. 48-59.

Воронятов С. В., Мачинский Д. А., 2010. О времени, обстоятельствах и смысле появления сарматских тамг на германских копьях // GermaniaSarmatia II : сб. науч. ст. по археологии народов Центральной и Восточной Европы, посвящ. памяти М.Б. Щукина. Калининград ; Курск. С. 57-77.

Го Бин, 2010. Концевые диски: характеристика китайских древних черепиц. Тайюань : Шаньси жэньминь чубаньшэ. 228 с. (на кит. яз.).

Гугуев В. К., Трейстер М. Ю., 1995. Ханьские зеркала и подражания им на территории юга Восточной Европы // Российская археология. № 3. С. 143-156.

Давыдова А. В., 1995. Иволгинский археологический комплекс. Т. 1 : Иволгинское городище // Археологические памятники сюнну. СПб. : Фонд АзиатИКА. 97 с. +188 табл.

Давыдова А. В., 1996. Иволгинский археологический комплекс. Т. 2 : Иволгинский могильник // Археологические памятники сюнну. СПб. : Петербуржское Востоковедение. 176 с.

Давыдова А. В., Миняев С. С., 2003. Комплекс археологических памятников у села Дурены // Археологические памятники сюнну. СПб. : Фонд «АзиатИКА». 164 с.

Драчук В. С., 1975. Системы знаков Северного Причерноморья. Тамгообразные знаки северопонтийской периферии античного мира первых веков нашей эры. Киев : Наукова думка, $224 \mathrm{c}$.

Древнемонгольские города, 1965. М. : Наука. 296 с . Духовная культура Китая, 2008. Энциклопедия : в 6 т. Т. 3. Литература. Язык и письменность. М. : Вост. лит. 854 c.

Елихина Ю. И., Новикова О. Г., 2013. Исследование китайских лакированных чашечек эпохи Хань из коллекции Государственного Эрмитажа // Теория и практика археологических исследований. № 1 (7). С. 135-146.

Косяненко В. М., 1994. К вопросу о хронологии и ритуально-магической роли бронзовых зеркал из некрополя Кобякова городища (по материалам раскопок 1956-1962 гг.) // Историко-археологические исследования в Азове и на Нижнем Дону в 1993 году. Вып. 13. Азов. C. $43-56$.

Кравцова М. Е., 2004. История искусства Китая : учеб. пособие. СПб. : Лань. 960 с.

Краткий отчет о раскопках чуского погребения села Яоцзяган уезда Чжицзян провинции Хубэй, 1988 // Каогу. № 2. С. 157-168. (на кит. яз.). 
Краткое сообщение об анализе могил эпохи Цинь и Хань в районе Гуаньцзюй, 1999 // Вэньу. № 6. С. 26 -47. (на кит. яз.).

Кызласов И. Л., 1994. Рунические письменности евразийских степей. М. : Вост. лит. 327 с.

Ли Сяоцин, Нань Баошэн, 2003. Золотые и бронзовые изделия северного вида, найденные в последние годы в Люпине, уезде Циншуй, провинции Ганьсу // Вэньу. № 7. С. 4-17. (на кит. яз.).

Литвинский Б. А., 1968. Кангюйско-сарматский фарн (к историко-культурным связям племен южной России и Средней Азии). Душанбе : Дониш. 114 с. +6 табл.

Лубо-Лесниченко Е. И., 1975. Привозные зеркала Минусинской котловины. К вопросу о внешних связях древнего населения Южной Сибири. М. : Наука. 170 с. + 109 ил.

Лубо-Лесниченко Е. И., 1994. Китай на Шелковом пути (Шелк и внешние связи древнего и раннесредневекового Китая). М. : Вост. лит. 326 с.

Материалы по истории сюнну (по китайским источникам), 1968. Предисловие, перевод и примечания В. С. Таскина. М. : Наука. Гл. ред. вост. лит. $178 \mathrm{c}$.

Медведев А. П., 2008. Сарматы в верховьях Танаиca. M. : Tayc. 252 c.

Миняев С. С., Сахаровская Л. М., 2007. Элитный комплекс захоронений сюнну в пади Царам // Российская археология. № 1. С. 194-201.

Новгородова Э. А., 1984. Мир петроглифов Монголии. М. : Наука. Гл. ред. вост. лит. 168 с.

Объяснение черт китайских иероглифов. Рассказы о 1000 иероглифах, 2010. Сиань : Шэньси шифан дасюэ чубаньшэ. 510 с. (на кит. яз.).

Ольховский В. С., 2001. Тамга (к функции знака) // Историко-археологический альманах. Вып. 7. Армавир ; М. : АКМ. С. 100-109.

Подушкин А. Н., 2013. Сарматские тамги-знаки на керамике Южного Казахстана // Шестая Междунар. Кубан. конф. Краснодар : Экоинвест. C. $340-344$.

Полное собрание образцов орнамента Китая, 2009. Т. 2. Цзинань : Шаньдун мэйшу чубаньшэ. 382 с. (на кит. яз.).

Полосьмак Н. В., Чистякова А. Н., 2013. Завершить работу небес // Наука из первых рук. № 4 (52). C. 77-91.

Полосьмак Н. В., Богданов Е. С., 2016. Каталог ноинулинской коллекции (по материалам работы российско-монгольской экспедиции 20062012 гг.). Новосибирск : ИНФОЛИО. 176 с.

Пэрлээ Х., 1976. Изучение этногенеза монгольских народностей по родовым знакам : (Опыт историко-этнографического исследования). УланБатор : АН Монголии. 270 с. (на монг. яз.).
Равич И. Г., 1995. Особенности состава и технологии изготовления миниатюрных сарматских зеркал из белой бронзы // Российская археология. № 3. С. 157-164.

Руденко С. И., 1962. Культура хуннов и ноинулинские курганы. М. : Л. : Изд-во АН СССР. 203 с.

Самашев 3., Базылхан Н., Самашев С., 2010. Древнетюркские тамги. Алматы : АО «Абди компани». $168 \mathrm{c}$.

Серкина А. А., 1973. Опыт дешифровки древнейшего китайского письма. М. : Наука. Гл. ред. вост. лит. $132 \mathrm{c.}$

Симоненко А. В., 2010. «Гунно-сарматы» (к постановке проблемы) // Нижневолжский археологический вестник. Вып. 11. С. 392-402.

Симоненко А. В., Лобай Б. И., 1991. Сарматы Северо-Западного Причерноморья в I в. н.э. (погребения знати у с. Пороги). Киев : Наукова думка. 112 с.

Скрипкин А. С., 1994. О начале и некоторых особенностях функционирования северного ответвления Великого шелкового пути // Античная цивилизация и варварский мир : тез. докл. IV археол. семинара. Новочеркасск : Музей истории донского казачества : Изд-во КубГУ. С. 32-33.

Соломоник Э. И., 1959. Сарматские знаки Северного Причерноморья. Киев : Изд-во АН УССР. 179 с. +22 ил.

Толстов С. П., 1948. Древний Хорезм. Опыт историко-археологического исследования. М. : Издво МГУ. 440 с.

Топоров В. Н., Мейлах М. Б., 1988. Круг // Мифы народов мира. Энциклопедия. Т. 2. М. : Сов. энцикл. С. 18-19.

Ханьское погребение у насыпи Чэньдун, провинции Цзянсу, уезд Сыян, 2007 // Вэньу. № 7. С. 39-60. (на кит. яз.).

Хуннский могильник Дуурлиг-Нарс : каталог выставки, 2009. Улаанбаатар. 99 с. (на монг. яз.).

Чистякова А. Н., 2011. Анализ лаковых чашек эпохи Западная Хань по иероглифическим надписям (Ноин-Ула, Монголия) // Археология, этнография и антропология Евразии. № 4 (48). С. 83-89.

Чэнь Юнчжи, 2003. Черепицы из Внутренней Монголии. Пекин : Вэньу чубанышэ. 310 с. (на кит. яз.).

Шрамко Б. А., 1962. Древности Северного Донца. Харьков : Изд-во Харьк. гос. ун-та. 404 с.

Яценко С. А., 2001. Знаки-тамги ираноязычных народов древности и раннего средневековья. М. : Вост. лит. 190 с.

Imperial China. The art of the horse in Chinese history, 2000. Exhibition catalog. Kentucky: Horse park. $183 \mathrm{p}$.

Jänichen H., 1956. Bildzeichen der königlichen Hoheit bei den iranischen Völkern. Bonn : Rudolf Habelt Verlag. 55 s. +30 Taf. 
Pirazzoli-t'Serstevens M., 2009. Chinese Lacquerware from Noyon uul: Some Problems of Manufacturing and Distribution // The Silk Road. Autumn. Vol. 7. P. 36- 41 .

Shanlin Gai, Yudong Lou, 1993. The rock arts of China. Beijing : Wenwu. 197 p. (на кит. яз.).

The ancient culture of Nangnang, 2001. Seul : The National Museum of Korea and Sol Publication Со. 294 р. (на кор. яз.).

Treasures of the Xiongnu, 2011. Culture of Xiongnu, the first Nomadic Empire in Mongilia, 2011. Catalog. Ulaanbaatar. 296 р. (на монг. яз.).

Umehara S., 1960. Studies of Noin-Ula finds in north Mongolia. Series A. № 27. Tokyo : The Toyo Bunko publications. 301 р. (на яп. яз.).

Wei Jie, 2008. Elementary introduction on seal producing with tile end inscription // Sichuan cultural relics. № 5. Р. 97-99 (на кит. яз.).

\section{REFERENCES}

Bartseva T.B., 1971. Preliminary results of a spectral study of the mirrors suspensions of the Central Caucasus. Istorija i kul tura Vostochnoj Evropy. Trudy GIM. Moscow, Gosudarstvennyi istoricheskii muzei, pp. 133-138. (in Russian).

Bezrukov A.V., 2000. Sarmatians of the Southern Urals and the Lower Volga Region on the Great Silk Road. Problemy istorii, filologii, kultury, iss. IX. Moscow; Magnitogorsk, Izd-vo Magnitog. un-ta, pp. 149-155. (in Russian).

Bezuglov S.I., Tolochko I.V., 2006. About the cultural and historical ties of the Tanais population in the era of the migration of peoples (based on burial materials). Drevnosti Bospora: sb. nauch. st., iss. 10, Moscow, IA RAN, pp. 89-110. (in Russian).

Bogdanov E.S., 2006. The image of a predator in the plastic art of the nomadic peoples of Central Asia (the Scythian-Siberian art tradition). Novosibirsk, Izd-vo IAET SO RAN. 240 p. (in Russian).

Bogdanov E.S., 2009. Art of the Xiongnu: old concepts, new facts. "Homo eurasicus" $u$ vrat iskusstva. St. Petersburg, Asterion, pp. 212-217. (in Russian).

Botalov S.G., Gutsalov S.Yu., 2000. Hun-Sarmatians of the Ural-Kazakh steppes. Chelyabinsk, Rifey Publ. 267 p. (in Russian).

Vainberg B.I., Novgorodova E.A., 1976. Notes on the Signs and Tamgas of Mongolia. Istoriia $i$ kultura narodov Srednei Azii. Moscow, Nauka Publ., pp. 66-74, 176-179. (in Russian).

Wang Ganghuai, 2015. Early Chinese mirrors. Shanghai, Shanghai Guzhi Chubanshe Publ. 199 p. (in Chinese).
Wang Chenyi, 2011. Collection of the best mirrors of China. Zhenzhou, Zhongzhou guji chubanshe Publ. 248 p. (in Chinese).

Voronyatov S.V., 2009. About functions of Sarmatian tamgas on vessels. Gunny, goty $i$ sarmaty mezhdu Volgoi i Dunaem. St. Petersburg, Fakultet filologii i iskusstv SPbGU, pp. 80-98. (in Russian).

Voronyatov S.V., 2013. Central Asia and North Pontic Area: Parallels Between ltems with Tamgas. The Lower Volga Archaeological Bulletin, iss. 13, pp. 48-59. (in Russian).

Voronyatov S.V., Machinskii D.A., 2010. On the time, circumstances and the meaning of the appearance of Sarmatian tamgas on the German spears. Germania - Sarmatia II: sb. nauch. st. Kaliningrad; Kursk, pp. 57-77. (in Russian).

Go Bin, 2010. End discs: a characteristic of Chinese ancient shingles. Taiyuan, Shanxi People's Chubanshe Publ. 228 p. (in Chinese).

Guguev V.K., Treister M.Yu., 1995. Han Mirrors and their Replicas in the Territory of South of Eastern Europe. Rossiyskaya arkheologiya, no. 3, pp. 143-156. (in Russian).

Davydova A.V., 1995. Ivolginsky archaeological complex. Vol. 1. Ivolginsky fortified settlement. Arkheologicheskie pamiatniki siunnu. St. Petersburg, Asiatika Publ. 97 p. +188 table (in Russian).

Davydova A.V., 1996. Ivolginsky archaeological complex. Vol. 2. Ivolginsky burial ground. Arkheologicheskie pamiatniki siunnu. St. Petersburg, Petersburg Oriental Studies Publ. 176 p. (in Russian).

Davydova A.V., Minyaev S.S., 2003. A complex of archaeological monuments near the village of Duryony. Arkheologicheskie pamiatniki siunnu. St. Petersburg, Asiatika Publ. 164 p. (in Russian).

Drachuk V.S., 1975. Systems of signs of the Northern Pontic Region. Tamgas-shaped signs of the North Pontic periphery of the antique world of the first centuries AD. Kiev, Naukova Dumka Publ. 224 p. (in Russian).

Ancient Mongolian cities, 1965. Moscow, Nauka Publ. 296 p. (in Russian).

Spiritual Culture of China, 2008. Encyclopedia in six volumes. Vol. 3. Literature. Language and writing. Moscow, Vostochnaya Literatura Publ. 854 p. (in Russian).

Yelikhina Yu.I., Novikova O.G., 2013. Study of Chinese lacquered cups of the Han period from the collection of the State Hermitage. Teoriia $i$ praktika arkheologicheskikh issledovanii, no. 1 (7). Barnaul, Izd-vo AGU, pp. 135-146. (in Russian). 
Kosyanenko V.M, 1994. On the Chronology and RitualMagical Role of Bronze Mirrors from the necropolis of Kobyakovo ancient settlement (according to the materials of the excavations 1956-1962). Istoriko-arkheologicheskie issledovaniia v Azove i na Nizhnem Donu v 1993 godu, iss. 13. Azov, pp. 43-56. (in Russian).

Kravtsova M.E., 2004. History of art in China. Tutorial. St. Petersburg, Lan Publ. 960 p. (in Russian).

A short report on the excavation of the Chu burial of the village of Yaojiaang, Zhijiang County, Hubei Province, 1988. Kaogu, no. 2, pp. 157-168. (in Chinese).

A brief report on the analysis of the graves of the Qin and Han epochs in the area of Guanjui, 1999. Wenwu, no. 6, pp. 26-47. (in Chinese).

Kyzlasov I.L, 1994. Runic scripts of the Eurasian steppes. Moscow, Vostochnaya literatura Publ. 327 p. (in Russian).

Li Xiaoqing, Nan Baosheng, 2003. Gold and bronze products of the northern species, found in recent years in Lupine, Qingshui County, Gansu Province. Wenwu, no. 7, pp. 4-17. (in Chinese).

Litvinskiy B.A., 1968. The Kangyu-Sarmatian farn (to the historical and cultural ties of the tribes of southern Russia and Central Asia). Dushanbe, Donish Publ. $114 \mathrm{p}+6$ table. (in Russian).

Lubo-Lesnichenko E.I., 1975. Import mirrors of the Minusinsk hollow. On the issue of external relations of the ancient population of Southern Siberia. Moscow, Nauka Publ. 170 p. (in Russian).

Lubo-Lesnichenko E.I., 1994. China on the Silk Road (Silk and external links of ancient and early medieval China). Moscow, Vostochnaya literatura Publ. 326 p. (in Russian).

Materials on the history of the Xiongnu (according to the Chinese sources), 1968. Introduction, translation and notes by V.S. Taskin. Moscow, Nauka Publ. Glavnaia redaktsiia vostochnoi literatury. 178 p. (in Russian).

Medvedev A.P., 2008. The Sarmatians in the upper reaches of Tanais. Moscow, Taus Publ. 252 p. (in Russian).

Minyaev S.S., Sakharovskaya L.M., 2007. Elite complex of graves of the Xiongnu in the Padi Tsaram. Rossiyskaya arkheologiya, no. 1, pp. 194-201. (in Russian).

Novgorodova E.A., 1984. The world of petroglyphs of Mongolia. Moscow, Nauka Publ. Glavnaia redaktsiia vostochnoi literatury. 168 p. (in Russian).

The explanation offeatures of Chinese characters Tales of 1000 characters, 2010. Xi'an, Shaanxi Shifang dasyue chubanshe Publ. 510 p. (in Chinese).

Olkhovsky V.S., 2001. Tamga (to the function of the sign). Istoriko-arkheologicheskii almanakh, iss. 7. Armavir; Moscow, AKM Publ., pp.100109. (in Russian).

Podushkin A.N, 2013. Sarmatian tamgas signs on the ceramics of Southern Kazakhstan. Shestaia mezhdunarodnaia kubanskaia konferentsiia. Krasnodar, Ecoinvest Publ., pp. 340-344. (in Russian).

Complete Collection of Chinese ornament samples, 2009. Vol. 2. Jinan, Shandong meyshu chubanshe Publ. 382 p. (in Chinese).

Polosmak N.V., Chistyakova A.N., 2013. Complete the work of the heavens. Science first hand, no. 4 (52), pp. 77-91. (in Russian).

Polosmak N.V., Bogdanov E.S., 2016. Catalog of the Noin-Ula collection (based on the work of the Russian-Mongolian expedition 2006-2012). Novosibirsk, INFOLIO Publ. 176 p. (in Russian).

Perlee H., 1976. Studying the Mongolian nationalities by generic signs. (The experience of historical and ethnographic research). Ulaanbaatar. 270 p. (in Mongolian).

Ravich I.G., 1995. Features of the composition and technology of manufacturing miniature Sarmatian mirrors of white bronze. Rossiyskaya arkheologiya, no. 3, pp. 157-164. (in Russian).

Rudenko S.I., 1962. Culture of the Xiongnu and Noinulinsky Mounds. Moscow; Leningrad, Izd-vo Akademii nauk USSR. 203 p. (in Russian).

SamashevZ., Bazylkhan N., Samashev S., 2010. Ancient Türkic Tamghas. Alma-Ata, JSC Abdi kompani Publ. 168 p. (in Russian, Kazakh).

Serkina A.A., 1973. The experience of deciphering ancient writing in Chinese. Moscow, Nauka Publ. Glavnaia redaktsiia vostochnoi literatury. 132 p. (in Russian).

Simonenko A.V., 2010. "Hun-Sarmatians" (to the formulation of the problem). The Lower Volga Archaeological Bulletin, iss. 11, pp. 392-402. (in Russian).

Simonenko A.V., Lobai B.I., 1991. The Sarmatians of the North-Western Pontic region in the first century BC (elite burials near village Porogi). Kiev, Naukova Dumka Publ. 112 p.

Skripkin A.S., 1994. About the beginning and some features of functioning of the northern branch of the Great Silk Road. Antichnaia tsivilizatsiia $i$ varvarskii mir. Materials of the $4^{\text {th }}$ archaeological seminar. Novocherkassk, Muzei istorii donskogo kazachestva; KubGU, pp. 32-33. (in Russian).

Solomonik E.I., 1959. Sarmatian signs of the Northern Pontic Region. Kiev, Izd-vo Akademia nauk Ukrainian SSR Publ. 179 p. (in Russian).

Tolstov S.P., 1948. Ancient Khorezm. The experience of historical and archaeological research. Moscow, Izd-vo Moscow State University. 440 p. (in Russian). 
Toporov V.N., Meilakh M.B., 1988. Circle. Mify narodov mira. Encyclopedia, vol. 2. Moscow, Sovetskaya Encyclopedia, pp. 18-19. (in Russian).

Han burial mound at Chendun, Jiangsu province, county Syyan, 2007. Wenwu, no. 7, pp. 39-60. (in Chinese).

Xiongnu burial ground of Durlig Nars. Exhibition catalog, 2009. Ulaanbaatar. 99 p. (in Mongolian).

Chistyakova A.N., 2011. Lacquer cups of the Western Han Dynasty (Noin Ula, Mongolia): An analysis of inscriptions. Archaeology, ethnology and anthropology of Eurasia, no. 4 (48), pp. 83-89. (in Russian).

Chen Yongzhi, 2003. Tiles from Inner Mongolia. Beijing, Wenwu Chubanshe Publ. 310 p. (in Chinese).

Shramko B.A., 1962. Antiquities of the Northern Don. Kharkov, Izd-vo Kharkov state university. 404 p. (in Russian).

Yatsenko S.A., 2001. Signs-tamgas of Iranianspeaking peoples of antiquity and early Middle Ages. Moscow, Vostochnaya literatura Publ., 190 p. (in Russian).
Imperial China. The art of the horse in Chinese history, 2000. Exhibition catalog. Kentucky, Horse park. 183 p.

Jänichen H., 1956. Bildzeichen der kunniglichen. Hoheit bei den iranischen Völkern. Bonn, RudolfHabelt Verlag. 55 s. +30 Taf.

Pirazzoli-t'Serstevens M., 2009. Chinese lacquerware from Noyon uul. Some Problems of Manufacturing and Distribution. The Silk Road. Autumn, vol. 7, pp. 36-41.

Shanlin Gai, Yudong Lou, 1993. The rock arts of China. Beijing, Wenwu Publ. 197 p. (in Chinese)

The ancient culture of Nangnang, 2001. Seul, The National Museum of Korea and Sol Publication Co., 294 p. (in Korean).

Treasures of the xiongnu, 2011. Culture of xiongnu, the first nomadic empire in Mongolia. Catalog. Ulaanbaatar. 296 p. (in Mongolian).

Umehara S., 1960. Studies of Noin-Ula finds in north Mongolia. Series A, no. 27. Tokyo, The Toyo Bunko Publ., 301 p. (in Japanese).

Wei Jie, 2008. Elementary introduction on seal producing with tile end inscription. Sichuan cultural relics, no. 5, pp. 97-99 (in Chinese).

\section{Information about the Author}

Evgeniy S. Bogdanov, Candidate of Sciences (History), Institute of Archaeology and Ethnography, Siberian Branch of RAS, Prosp. Akademika Lavrentyeva, 17, 630090 Novosibirsk, Russian Federation, bogdanov@archaeology.nsc.ru.

\section{Информация об авторе}

Евгений Сергеевич Богданов, кандидат исторических наук, Институт археологии и этнографии СО РАН, просп. академика Лаврентьева, 17, 630090 г. Новосибирск, Российская Федерация, bogdanov@archaeology.nsc.ru. 